$$
\begin{aligned}
& N=25 \\
& 04139
\end{aligned}
$$

NASA Technical Memorandum 107485

AIAA-97-3041

\title{
Evaluation of Heat Transfer and Thermal Stability of Supercritical JP-7 Fuel
}

Diane L. Linne and Michael L. Meyer

Lewis Research Center

Cleveland, Ohio

Tim Edwards

Wright Laboratory

Wright Patterson Air Force Base, Ohio

David A. Eitman

Science Applications International Corporation

Fountain Valley, California

Prepared for the

33rd Joint Propulsion Conference and Exhibit cosponsored by AIAA, ASME, SAE, and ASEE

Seattle, Washington, July 6-9, 1997

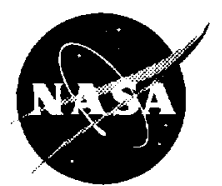

National Aeronautics and

Space Administration 



\title{
EVALUATION OF HEAT TRANSFER AND THERMAL STABILITY OF SUPERCRITICAL JP-7 FUEL
}

\author{
Diane L. Linne and Michael L. Meyer \\ National Aeronautics and Space Administration \\ Lewis Research Center \\ Cleveland, Ohio 44135 \\ Tim Edwards \\ Wright Laboratory \\ Wright Patterson Air Force Base, Ohio \\ David A. Eitman \\ Science Applications International Corp. \\ Fountain Valley, California
}

\begin{abstract}
$\underline{\text { Abstract }}$
A series of electrically heated tube experiments was conducted to investigate the potential of JP-7 as a coolant under conditions relevant to a Mach 8 propulsion system. The heat transfer capabilities, carbon deposition, and material compatibility of JP-7 at surface temperatures up to $1700^{\circ} \mathrm{F}\left(927^{\circ} \mathrm{C}\right)$ were tested in 0.125 in. diameter tubes of 304 SS, Inconel 617, Haynes 188, Haynes 230, and $50 / 50$ Moly-Rhenium. The heat transfer to the coolant was modeled well by a Dittus-Boelter correlation at lower heat fluxes. At higher heat fluxes, audible instabilities were observed and corresponded to a significant enhancement in the coolant heat transfer. The carbon deposition rates in these tests were comparable to those in previous experiments at lower heat fluxes and much longer residence times. This result suggests that alternative paths of the deposition mechanism may be enhanced under high heat flux test conditions. Microscopic investigation of the post test tubes indicated that there was a significant layer of ordered carbon deposits that had not been seen in the tests at lower heat flux.
\end{abstract}

\section{Introduction}

Hypersonic flight places severe requirements on the fuel, both as a propellant and as a coolant. Hydrocarbon fuels are limited to approximately Mach 8 primarily by their coolant capabilities, ${ }^{1}$ although their combustion properties also have significant limitations. ${ }^{2}$ Steady state temperatures in Mach 8 combustors can reach as high as $5000^{\circ} \mathrm{F}\left(2760^{\circ} \mathrm{C}\right)^{3}$ which will require regenerative cooling of the combustor. As part of the Air Force Hypersonic Technology (HyTech) program, the Materials and Aero Propulsion and Power Directorates of Wright Laboratory are examining fuel/material compatibility issues for hydrocarbon-fueled Mach 8 vehicles. Various metallic alloy candidates for regenerative cooling systems have been examined, including commercial superalloys and moly-rhenium (MoRe) alloys which were previously studied under the National Aerospace Plane program. ${ }^{4}$

A major concern for high temperature hydrocarbon fuels is the formation of coke. There are various types of coke that can be formed, with the most deleterious being filamentous (catalytic) coke. ${ }^{5,6}$ Filamentous coke is formed by surface carbon diffusing through metals, precipitating out at grain boundaries, and catalytically growing carbon filaments that include grains of the metal surface. This type of carbon formation reduces metal strength and ductility and is obviously undesirable. In general, all types of coke formation are undesirable in that they reduce heat transfer by acting as an insulator on surfaces, and can clog small passages in fuel systems and injectors. Most of the literature on high temperature coke formation is based on industrial applications at near-atmospheric pressures, often diluted with steam; there is little research at the high pressures expected in hypersonic vehicle fuel systems (1000 psi, 6.9 MPa).

Wright Laboratories has confirmed the formation of filamentous carbon for fuels heated to $1000^{\circ} \mathrm{F}\left(540^{\circ} \mathrm{C}\right)$ at $1000 \mathrm{psi}(6.9 \mathrm{MPa})$, but the heat flux was much lower than the $500 \mathrm{Btu} / \mathrm{ft}^{2}-\mathrm{s}\left(570 \mathrm{~W} / \mathrm{cm}^{2}\right)$ or more that is expected in

Copyright $\odot$ by the American Institute of Aeronautics and Astronautics, Inc. No copyright is asserted in the United States under Title 17, U.S. Code. The U.S. Government has a royalty-free license to exercise all rights under the copyright claimed herein for Governmental Purposes. All other rights are reserved by the copyright owner. 
a Mach 8 propulsion system. In addition, it is anticipated that wall temperatures may reach $1800^{\circ} \mathrm{F}\left(980^{\circ} \mathrm{C}\right)$ during hypersonic flight. Previous work has determined that some of the key parameters that affect the coke deposition are heat flux, fuel temperature and pressure, surface temperature, fuel residence time, and fuel composition. Further tests at Wright Laboratories extended the database by reaching surface temperatures of $1400^{\circ} \mathrm{F}\left(760^{\circ} \mathrm{C}\right)$. No reduction in material strength was found after 2 hours of exposure for a variety of superalloys and a MoRe alloy. ${ }^{8}$ These tests, however, were also limited to low heat fluxes and long fuel residence times (i.e., low flow rates).

This paper describes results from heated tube tests with JP-7 cooling with surface temperatures up to $1700^{\circ} \mathrm{F}$ $\left(927^{\circ} \mathrm{C}\right)$. Fuel flow rate and heat flux were also much higher than the previous tests, and were more typical of conditions expected in hypersonic flight. The experimental cooling capability of the JP-7 was compared to two standard heat transfer coefficient correlations. The carbon deposition rate was also quantified, and compared with the earlier results at lower heat flux. Finally, several tubes were sectioned and examined microscopically for failure and coking mechanisms.
Test Facility. Hardware, and Procedure

The tests were conducted in the NASA Lewis Research Center Heated Tube Facility. The combustible liquids system was used for these tests. The entire facility is described in detail in reference 9.

\section{Facility}

A simplified schematic of the combustible liquids system is shown in Fig. 1. The test section was mounted vertically within a vacuum chamber that was kept below $0.01 \mathrm{psi}(69 \mathrm{~Pa})$. The vacuum environment minimized heat losses due to convection and provided a measure of safety in the event of a fuel leak. The test section was heated electrically by passing a current through the tube. Four direct current power supplies were available, each capable of 1500 amps and $80 \mathrm{~V}$. The coolant fuel was stored in a supply tank rated for pressures up to $1650 \mathrm{psi}$. The coolant flowed from the supply tank through the test section and back through a heat exchanger to the return tank. Separate valves were used for flow rate and test section back pressure control. For this test series, the control valves were pneumatically actuated and were

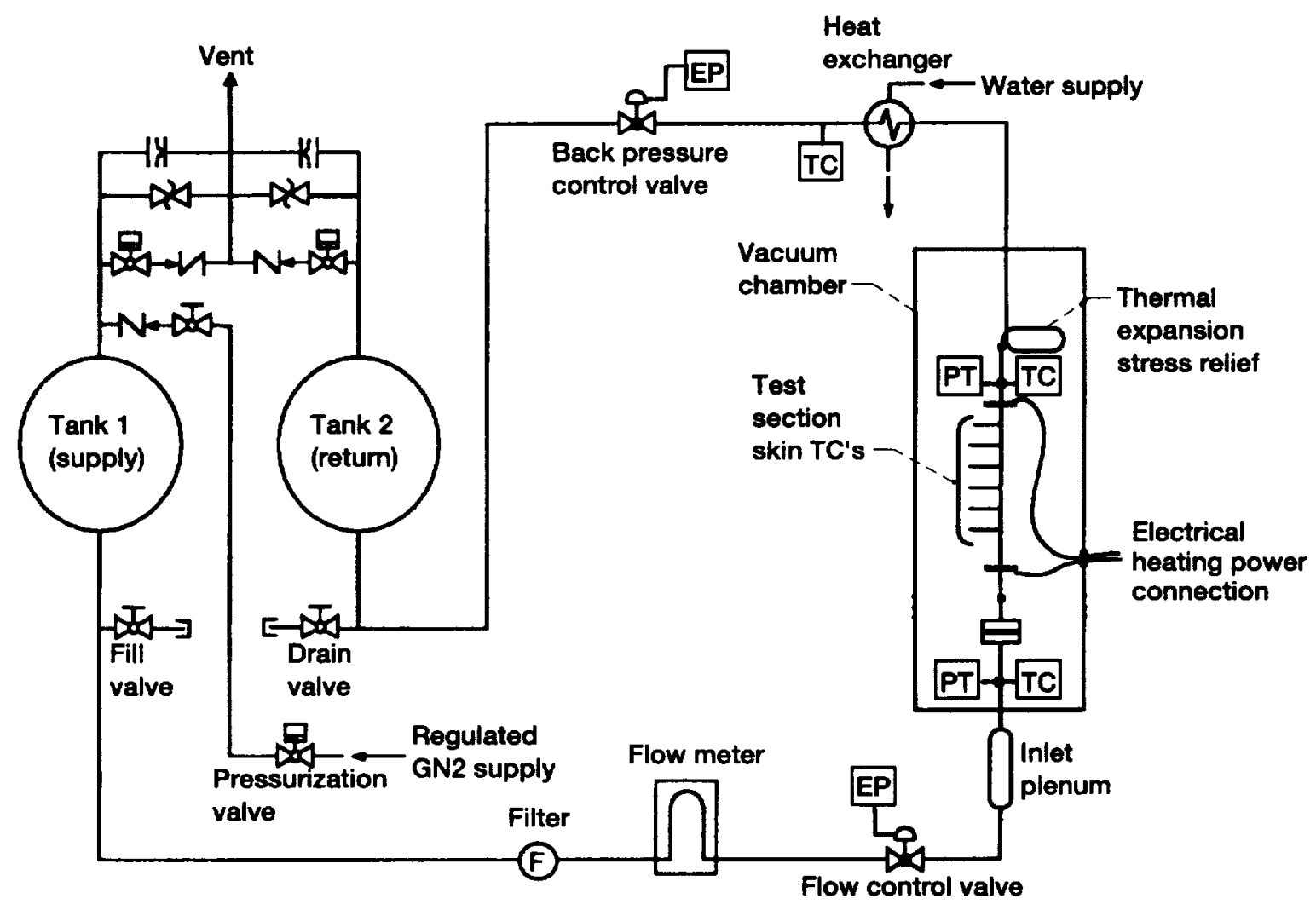

Figure 1.-Schematic of combustible liquid flow system in the heated tube facility. 
sized for a nominal flow rate of $0.0345 \mathrm{lbm} / \mathrm{s}(15.6 \mathrm{gm} / \mathrm{s})$. A Coriolis-force flow meter was used to provide accurate flow measurement of the JP-7 fuel. The coolant temperature and pressure were measured at the inlet and exit of the test section by thermocouples and pressure transducers, and heat input was determined by recording the voltage and current applied to the test section. Each of the facility and research instrumentation was recorded on the facility's data system at a rate of one complete cycle per second.

\section{Test Hardware}

The test sections for these tests were fabricated from 0.125 in. $(0.318 \mathrm{~cm})$ outside diameter by 0.015 in. $(0.038 \mathrm{~cm})$ wall tubes of the following alloys: 304 stainless steel, Inconel 617, Haynes 188, Haynes 230, and Molybdenum/Rhenium at approximately 50 percent each (MoRe). The one exception was that the wall thickness of the stainless steel tube was 0.016 inch $(0.041 \mathrm{~cm})$. The total test section length was 18 in. $(45.7 \mathrm{~cm})$ and was connected to 0.25 in. $(0.64 \mathrm{~cm})$ tubing at the inlet. Of the total length, 14 in. $(35.6 \mathrm{~cm})$ were heated electrically. Copper disks of 0.5 in. $(1.3 \mathrm{~cm})$ thickness were brazed to the tube in a vacuum furnace braze process. The brazing alloy was selected for a liquidus temperature low enough that the tube material properties would not be affected during brazing but a remelt temperature higher than it would be exposed to during testing. The copper disks provided convenient electrical connection for heating.

The test sections were instrumented with six type $K$ thermocouples which were spot welded directly to the outer surface of the tube. The thermocouples were located at $1,2,5,9,12$, and 13 in. $(2.5,5.1,12.7,22.9,30.5$, and $33.0 \mathrm{~cm}$ ) from the start of the heated section (Fig. 2). Each test section was calibrated in a water cooled calibration rig prior to testing to check and correct for induced temperature error caused by the voltage in the tube. Reference 10 discusses this error potential, and the method used to correct for it if present.

At an operating pressure of $1000 \mathrm{psi}(6.9 \mathrm{MPa})$, hoop stress on the tubes was approximately $3200 \mathrm{psi}(22 \mathrm{MPa})$. Table I lists the tensile strength of the materials tested. It can be seen that the hoop stresses encountered in these experiments were still well below the failure point of the tubes.

\section{Coolant Properties}

Thermophysical properties of $n$-dodecane $\left(\mathrm{C}_{12} \mathrm{H}_{26}\right)$ were used to model the JP-7 fuel. ${ }^{11}$ The n-dodecane properties were obtained from the National Institute of Standards and Technology reference database. ${ }^{12}$ Prandtl

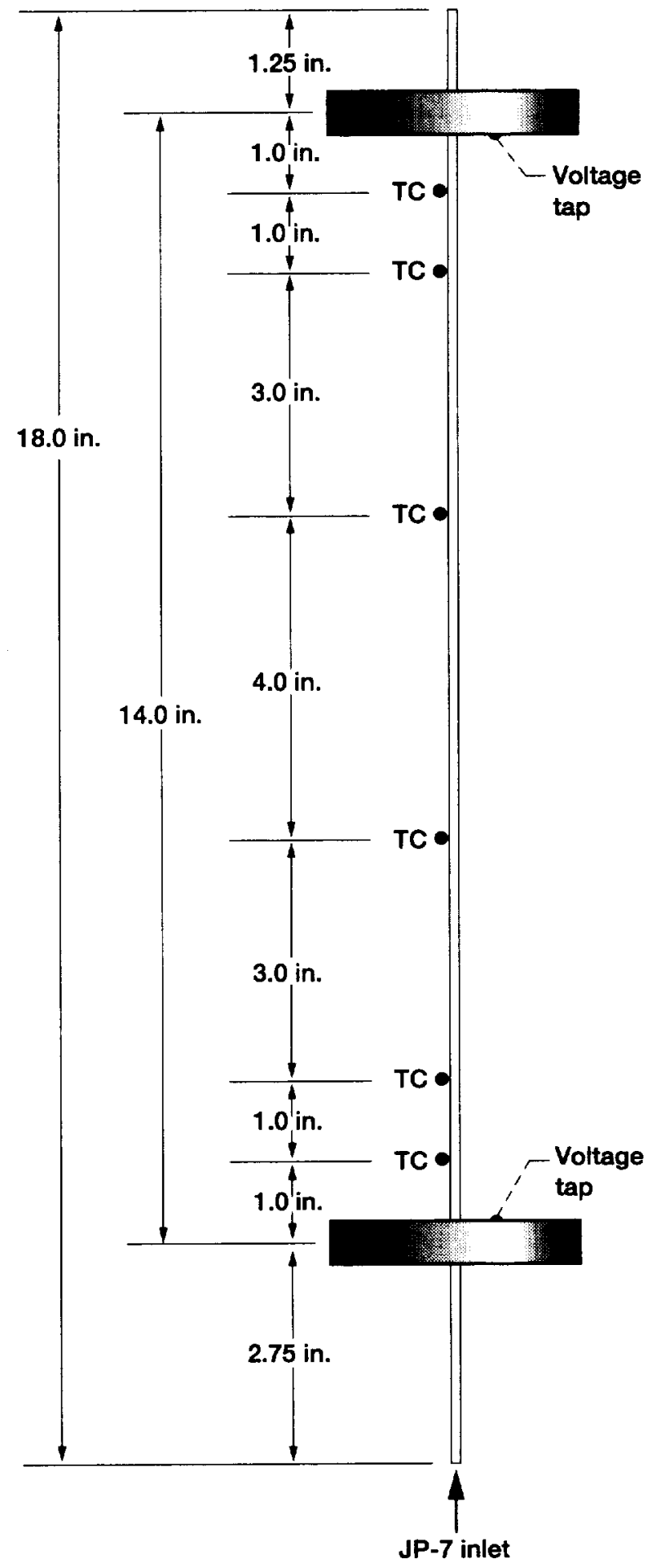

Figure 2.- Schematic of test section hardware and instrumentation. (TC = thermocouple) 
TABLE I. - HIGH-TEMPERATURE TENSILE STRENGTH OF TESTED MATERIALS

\begin{tabular}{|l|c|c|}
\hline \multicolumn{1}{|c|}{ Material } & $\begin{array}{c}\text { Temperature, } \\
{ }^{\circ} \mathrm{F}\end{array}$ & $\begin{array}{c}\text { Tensile strength, } \\
\mathbf{k l b f} / \text { in }^{2}\end{array}$ \\
\hline 304 SS & 1800 & 8.5 \\
\hline INCONEL 617 & 2000 & 10 \\
\hline HAYNES 188 & 2000 & 18.7 \\
\hline HAYNES 230 & 2000 & 19.5 \\
\hline MoRe & 2000 & 50 \\
\hline
\end{tabular}

number varied from 21 at ambient temperature to approximately 3.5 at temperatures near $850^{\circ} \mathrm{F}\left(450^{\circ} \mathrm{C}\right)$. Critical conditions were assumed to be $260 \mathrm{psi}$ and $760^{\circ} \mathrm{F}$ (1.8 $\mathrm{MPa}$ and $404^{\circ} \mathrm{C}$ ).

\section{Procedure}

A typical test run procedure started by filling the supply tank with JP-7 and pressurizing the ullage with gaseous nitrogen. The empty return tank was vented to the atmosphere. The coolant flow was stabilized at flow rate $(0.0345 \mathrm{lbm} / \mathrm{sec})$ and back pressure (1000 psi) set points prior to turning on the electrical heating power supplies. The power was increased in steps until the desired wall temperatures were achieved. Figure 3 shows the profiles of fluid outlet temperature, heat flux, and coolant-side wall temperature versus test time for a representative test. The plots show the gradual increase in heat flux and temperatures that was necessary to avoid unstable conditions which could result in test section failure. The figure also shows a large fluctuation in wall temperature at the maximum heat flux that occurred in all of the tests.

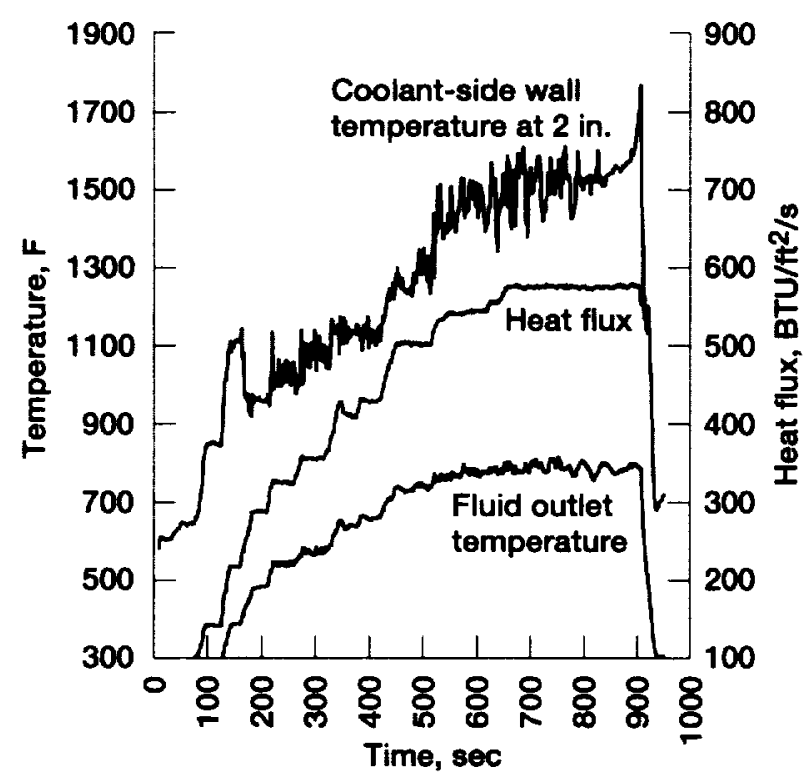

Figure 3.-Typical profile of wall temperature, heat flux, and fuel outlet temperature; test section 4, Haynes 230.
The test objective was to maintain wall temperature at a specified value (between $1400^{\circ} \mathrm{F}$ and $1800^{\circ} \mathrm{F} ; 760$ and $980{ }^{\circ} \mathrm{C}$ ) for $15 \mathrm{~min}$. Most tests, however, were ended before $15 \mathrm{~min}$ due to either a tube failure or rapidly rising temperatures. For example, the test shown in Fig. 3 was terminated when wall temperature began to rise rapidly at constant heat flux just after 900 sec. After a test was completed, the test section was removed and prepared for post-test carbon deposition and microscopic analysis.

Coolant side wall temperature was calculated from the hot side wall thermocouples using two methods. The first method was an iterative procedure that calculated local heat flux, electrical resistivity, and thermal conductivity for each tube portion containing a thermocouple. The second method used direct radial conduction assuming equal power distribution throughout the tube. Coolant wall temperatures calculated from the two methods were within one degree of each other. The temperature delta across the wall for 304 SS, Haynes 188, Haynes 230, and Inconel 617 were similar; they ranged from $85^{\circ} \mathrm{F}\left(47^{\circ} \mathrm{C}\right)$ at a heat flux of $575 \mathrm{Btu} / \mathrm{ft}^{2}-\mathrm{s}\left(653 \mathrm{~W} / \mathrm{cm}^{2}\right)$ to $106^{\circ} \mathrm{F}\left(59^{\circ} \mathrm{C}\right)$ at a heat flux of $720 \mathrm{Btu} / \mathrm{ft}^{2}-\mathrm{s}\left(817 \mathrm{~W} / \mathrm{cm}^{2}\right)$. For the Moly-Rhenium tube, the temperature delta across the wall was approximately $40^{\circ} \mathrm{F}\left(22^{\circ} \mathrm{C}\right)$ at a heat flux of $575 \mathrm{Btu} / \mathrm{ft}^{2}-\mathrm{s}\left(653 \mathrm{~W} / \mathrm{cm}^{2}\right)$.

\section{$\underline{\text { Results and Discussion }}$}

Table II summarizes the tests that were completed during this test program. Note that the hottest point in the tube was not always at the same location, even with the same tube material. Test sections number 2 (Haynes 188), 4 , and 5 (Haynes 230) were the only test sections that did not fail. All other test sections listed experienced some type of failure.

\section{Flow Ouality at Entry}

At ambient temperature and 1000 psi $(6.9 \mathrm{MPa})$ pressure, the viscosity of JP-7 is $0.00105 \mathrm{lbm} / \mathrm{ft}-\mathrm{sec}$ $\left(0.00156 \mathrm{~N}-\mathrm{s} / \mathrm{m}^{2}\right)$. These conditions provided an initial Reynolds number based on diameter of approximately 5275. As the JP-7 was heated, Reynolds number increased due to the decreasing viscosity. Typical Reynolds number calculated with bulk fluid conditions at the tube exit during a test was approximately 140000 . Both inlet and exit Reynolds number, therefore, were in the turbulent regime. For turbulent flow in a tube, the hydrodynamic entry length is independent of Reynolds number. Reference 13 suggests between 10 and 60 diameters for a first approximation, and states that 10 diameters is usually appropriate. With an internal diameter of 0.095 in. 
TABLE II. - SUMMARY OF TEST CONDITIONS AND RESULTS

\begin{tabular}{|c|c|c|c|c|}
\hline Tube material & $\begin{array}{c}\text { Test } \\
\text { section } \\
\text { number }\end{array}$ & $\begin{array}{l}\text { Maximum heat } \\
\text { flux, } \\
\text { Btu/ft } \mathrm{ft}^{2} \mathrm{sec}\end{array}$ & $\begin{array}{l}\text { Maximum coolant-wall temperature at } \\
\text { location for duration }\end{array}$ & $\begin{array}{c}\text { Comments } \\
\text { (including type and location of failure) }\end{array}$ \\
\hline $304 \mathrm{SS}$ & 1 & 720 & $\begin{array}{l}1450^{\circ} \mathrm{F} \text { at } 13 \text { in. for } 80 \mathrm{sec} \\
1550^{\circ} \mathrm{F} \text { at } 13 \text { in. for } 30 \mathrm{sec}\end{array}$ & $\begin{array}{l}\text { Bulging of tube; pinhole leaks in two } \\
\text { locations }\end{array}$ \\
\hline Haynes 188 & 2 & 650 & $\begin{array}{l}1450 \text { to } 1550{ }^{\circ} \mathrm{F} \text { at } 9 \text { in. for } 250 \mathrm{sec} \\
1500 \text { to } 1600{ }^{\circ} \mathrm{F} \text { at } 12 \mathrm{in} \text {. for } 160 \mathrm{sec}\end{array}$ & $\begin{array}{l}\text { At constant heat flux, wall temperatures } \\
\text { began to rise steadily and quickly; test } \\
\text { was stopped }\end{array}$ \\
\hline Haynes 188 & 3 & 575 & 1400 to $1500{ }^{\circ} \mathrm{F}$ at 1 and 5 in. for $70 \mathrm{sec}$ & $\begin{array}{l}\text { Tube failed as heat flux was increasing } \\
\text { from } 575 \text { to } 600 \mathrm{BTU} / \mathrm{ft}^{2}-\mathrm{sec} ; 0.5 \text { in. } \\
\text { axial split at } 5.5 \mathrm{in} \text {. }\end{array}$ \\
\hline Haynes 230 & 4 & 575 & $\begin{array}{l}1400 \text { to } 1600{ }^{\circ} \mathrm{F} \text { at } 2 \text { in. for } 370 \mathrm{sec} \\
\text { (reached } 1800^{\circ} \mathrm{F} \text { before shutdown) }\end{array}$ & $\begin{array}{l}\text { At constant heat flux, wall temperatures } \\
\text { began to rise steadily and quickly; test } \\
\text { was stopped }\end{array}$ \\
\hline Haynes 230 & 5 & 650 & 1650 to $1750{ }^{\circ} \mathrm{F}$ at $13 \mathrm{in}$. for $900 \mathrm{sec}$ & $\begin{array}{l}\text { Test was stopped after } 15 \mathrm{~min} \text { at target } \\
\text { temperature }\end{array}$ \\
\hline Haynes 230 & $\overline{6}$ & 720 & 1425 to $1575^{\circ} \mathrm{F}$ at $13 \mathrm{in}$. for $350 \mathrm{sec}$ & $\begin{array}{l}\text { Low-frequency oscillation in flow rate } \\
\text { and back pressure; lowered heat flux, } \\
\text { then increased again; at heat flux of } \\
500 \text { BTU/f }{ }^{2} \text {-sec, tube failed. Axial split } \\
\text { at } 5.5 \text { in., and piece separated from tube } \\
\text { from }-1.5 \text { to } 2.5 \text { in. }\end{array}$ \\
\hline Inconel 617 & 7 & 650 & 1450 to $1550^{\circ} \mathrm{F}$ at 13 in. for $320 \mathrm{sec}$ & $\begin{array}{l}\text { As heat flux was being raised to } 685 \\
\text { BTU/ } \mathrm{ft}^{2}-\mathrm{sec} \text {, wall temperatures rose } \\
\text { rapidly and tube failed; }-0.5 \text { in. axial } \\
\text { fracture at } 7 \text { in. }\end{array}$ \\
\hline Moly-Re & 8 & 575 & 1200 to $1400^{\circ} \mathrm{F}$ at 1 and 2 in. for $50 \mathrm{sec}$ & $\begin{array}{l}\text { Plastic deformation (bulge) and split at } \\
2 \text { in. }\end{array}$ \\
\hline
\end{tabular}

$(0.24 \mathrm{~cm})$, the 2.75 in. $(7.0 \mathrm{~cm})$ of tubing before the beginning of the heated section provided 29 diameters to develop flow before entering the heated test section. Therefore, fully developed turbulent flow was assumed throughout the test section.

The thermal entry length in a tube is also independent of Reynolds and Prandtl numbers for turbulent flow. Reference 13 recommends 10 diameters for the thermal entry length for turbulent flow. Ten diameters would occur just before the first thermocouple at $1 \mathrm{in} .(2.5 \mathrm{~cm})$. Therefore, the first thermocouple was considered to be at the end of the thermal entry region, with the remainder of the test section in the thermally fully developed region.

\section{Heat Transfer Correlations}

In order to determine the cooling characteristics of the JP-7 in the test section, the experimental Nusselt number was calculated according to:

$$
\mathrm{NU}=\frac{\mathrm{h}_{\mathrm{x}} * \mathrm{D}_{\mathrm{i}}}{\mathrm{k}_{\mathrm{f}}}
$$

where

$\mathrm{D}_{\mathrm{i}} \quad$ tube internal diameter

$\mathrm{k}_{\mathrm{f}}$ fluid thermal conductivity

$h_{x}$ experimental convective coefficient calculated by:

$$
h_{x}=\frac{q_{x}^{\prime \prime}}{\left(T_{c w}-T_{m}\right)}
$$

where $q_{\mathbf{x}}^{\prime \prime} \quad$ experimental heat flux

$T_{c w}$ coolant-side wall temperature

$\mathrm{T}_{\mathrm{m}} \quad$ local mean fluid temperature

The experimental Nusselt number was then compared to two empirical correlations. The first was the DittusBoelter equation: ${ }^{14}$

$\mathrm{NU}_{\mathrm{DB}}=0.023 * \operatorname{Re}^{0.8} * \operatorname{Pr}^{0.4}$ (for heating of the fluid)

The second correlation used was the Sieder-Tate equation ${ }^{15}$ which is recommended when there are large differences in fluid properties between the free-stream and near the wall:

$$
\mathrm{NU}_{\mathrm{ST}}=0.027 * \operatorname{Re}^{0.8} * \operatorname{Pr}^{0.333} *\left(\frac{\mu}{\mu_{\mathrm{w}}}\right)^{0.14}
$$

where all quantities are calculated with properties at the mean fluid temperature except for $\mu_{w}$, which is the viscosity at the wall temperature.

These three values of Nusselt number were plotted as a function of time for each thermocouple location for each tube. The Nusselt number curves for test section 4 
(Haynes 230) are representative of all the test sections, and are shown in Fig. 4. One consistent feature of the Nusselt number comparisons for all of the thermocouples on all of the tubes was that the experimental Nusselt number in the beginning of every test most closely resembled the DittusBoelter correlation. At some point during the test, however, as the heat flux was increased, the experimental Nusselt number transitioned from the Dittus-Boelter correlation to the Sieder-Tate correlation. This transition occurred around $160 \mathrm{sec}$ for test section 4 as shown in Fig. 4. The cooling characteristics after this transition occurred were inconsistent from one test section to another and even at different thermocouple locations within a test section. Figure 4(b) shows that the experimental Nusselt number at 9 in. $(22.9 \mathrm{~cm})$ was higher than the Sieder-Tate correlation for $300 \mathrm{sec}$ before returning to the Sieder-Tate value. At 12 in. $(30.5 \mathrm{~cm})$ (Fig. 4(c)), the experimental Nusselt number remained higher than the Sieder-Tate correlation for the remainder of the test.

As heat flux was increased during each test, the difference between wall and free stream temperature increased. It was therefore anticipated that the cooling characteristics would gradually transition from the DittusBoelter to the Sieder-Tate correlation. The difference between wall and free stream temperature, however, varied significantly along the length of the tube at any given time. This fact, along with the abruptness of the transition and the inconsistencies afterward implied that factors other than, or in addition to, radial viscosity variations caused the change in cooling characteristics.

The enhanced cooling that is indicated in the Nusselt number curves in Fig. 4 can be illustrated in a different manner as shown in Fig. 5. In this figure, heat flux is plotted as a function of coolant-side wall temperature. At lower heat flux, the wall temperature increases linearly with increasing heat flux. At some value of heat flux, however, there is a discontinuity where temperature drops, then increases more slowly and unevenly. This slower rate of wall temperature rise indicates an enhancement of the convective heat transfer coefficient. At the location shown in Fig. 5 ( 5 in.), this improvement is about 40 percent. The cooling enhancement, however, varied widely along the tube with an average of 100 percent.

Several factors could cause or contribute to the increase in the convective heat transfer coefficient of the JP-7 that is indicated in Figs. 4 and 5. The test data were reviewed in an attempt to discover a common variable that triggered the transition to the enhanced cooling regime. The first common variable was that the transition occurred at the same time throughout the length of the test section. That is, all six thermocouples measured the enhanced cooling
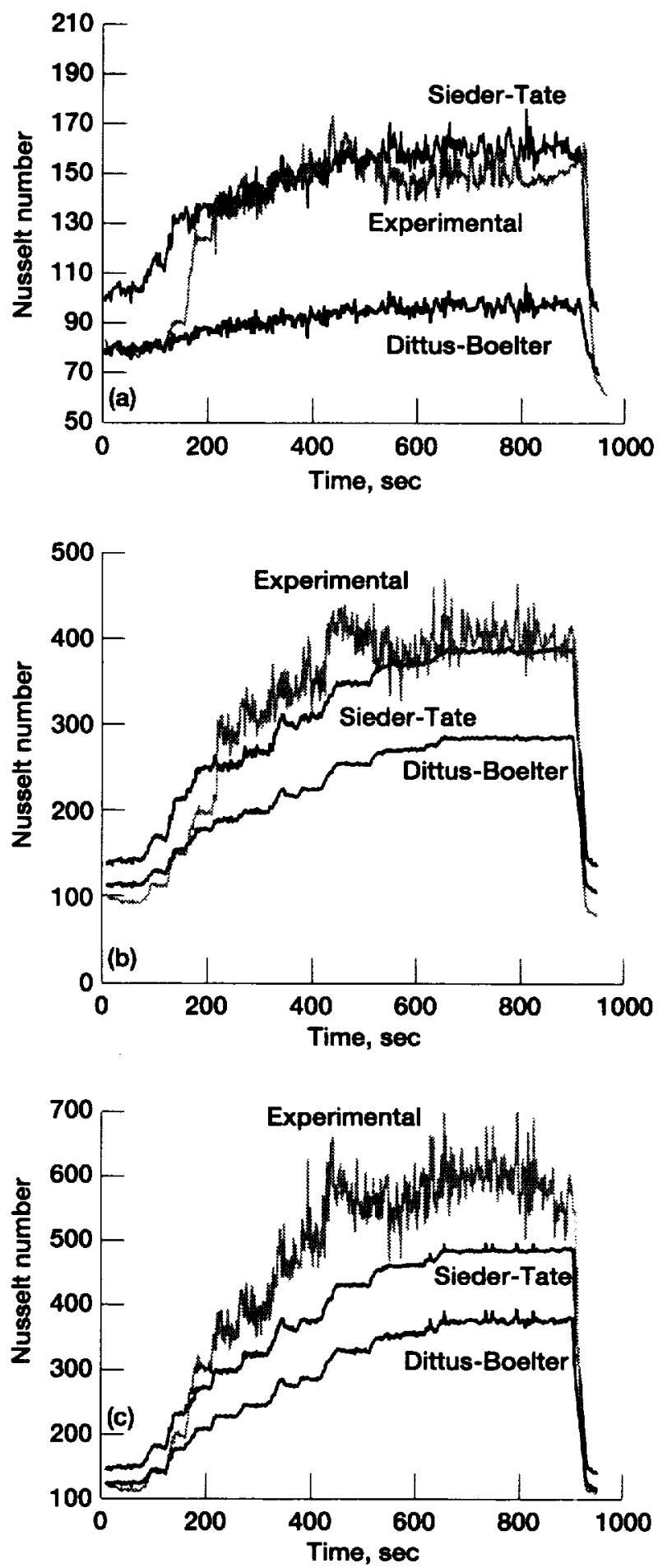

Figure 4.-Comparison of Nusselt numbers for test section 4, Haynes 230. (a) At 1 in. (b) At 9 in. (c) At 12 in. 


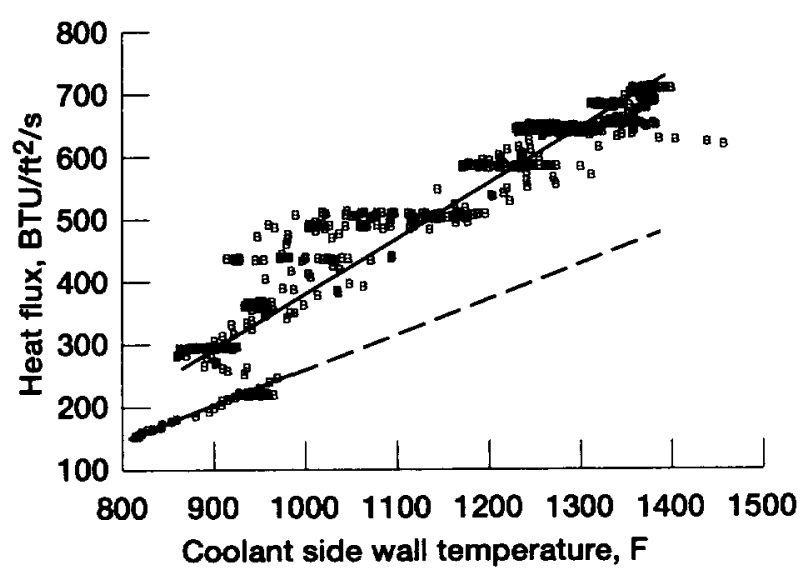

Figure 5.-Relationship between heat flux and wall temperature at 5 in. for test section 5 , Haynes 230.

effect simultaneously. This discounted any correlation with local Reynolds number, wall temperature, and local mean fluid temperature as these properties all vary axially along the length of the test section at a given time.

Other possible causes that were considered include roughness of the tube as carbon deposition began, an increase in radiative losses from the test section, large property variations near critical temperature, heat flux level, and flow instabilities. Although roughness was not measured in these tests, previous experiments at lower heat flux showed that the insulating properties of the carbon deposits proved to be more significant than any advantage gained by carbon deposits roughening the wall.

Radiative emissivity of a metal will increase with time at elevated temperatures, and radiative losses were calculated to see if these could cause an apparent increase in fluid cooling capability. However, assuming a change in emissivity from 0.3 to 0.8 , the radiative loss to the surroundings increases by only 1 percent of the total heat flux to the coolant, which is insufficient to account for a measured cooling capacity increase of over 40 percent.

The discontinuity and change in slope in Fig. 5 is similar to the experimental data discussed in reference 16 , where nickel tubes of similar dimensions were used to electrically heat RP-1 at supercritical pressures and suband supercritical temperatures. In those experiments, the cooling transition occurred when the wall temperature approached the critical temperature of the fuel. In our experiments, however, the wall temperatures were significantly higher (a minimum of $900{ }^{\circ} \mathrm{F}$ ) than the critical temperature of the JP-7 $\left(760^{\circ} \mathrm{F}\right)$ at the start of the transition.
Extensive theoretical and experimental analysis of subcritical fluids in heated tubes have also demonstrated similar curves. ${ }^{17}$ In subcritical fluids, the enhanced cooling region correlates to the onset of nucleate boiling. It has been suggested, therefore, that the enhanced cooling observed in fluids at supercritical pressures and sub- and supercritical temperatures is a supercritical fluid phenomena analogous to nucleate boiling, where pockets of low density fluid form near the wall like bubbles. This analogy has been proposed to explain experimental results of both hydrocarbon ${ }^{16}$ and hydrogen ${ }^{18}$ cooling. At the time of transition in our tests the density near the wall was 2.3 to 3.5 times lower than the bulk fluid density. However, the magnitude of the heat transfer enhancement was greater than expected because this density variation from bulk fluid temperature to wall temperature is much less at the operating pressures in these tests than at sub- or nearcritical pressures. In a subcritical fluid, nucleate boiling changes to film boiling at a critical heat flux. This change is often abrupt, and can cause runaway temperatures resulting in failure of the tube material. The sudden, runaway temperatures experienced in this program are again similar to results from subcritical cooling.

The only variable that was consistent along the tube at any given time frame was heat flux. In order to investigate whether heat flux was the trigger for the onset of the enhanced cooling, the data from three test sections of Haynes 230 were compared (test sections 4,5 , and 6 ). The heat flux at which the transition to enhanced cooling occurred was similar for all three tubes. It occurred at a heat flux of approximately $240 \mathrm{Btu} / \mathrm{ft}^{2}-\mathrm{s}\left(272 \mathrm{~W} / \mathrm{cm}^{2}\right)$ for test section $4,245 \mathrm{Btu} / \mathrm{ft}^{2}-\mathrm{s}\left(278 \mathrm{~W} / \mathrm{cm}^{2}\right)$ for test section 5 , and $260 \mathrm{Btu} / \mathrm{ft}^{2}-\mathrm{s}\left(295 \mathrm{~W} / \mathrm{cm}^{2}\right)$ for test section 6 . The bulk fluid outlet temperature was also similar for all three test sections, between 390 and $420{ }^{\circ} \mathrm{F}$ (200 and $\left.216{ }^{\circ} \mathrm{C}\right)$. The wall temperature profiles, however, varied among the three tubes, both in temperature and in shape of the profile along the tube. Figure 6 shows the coolant-side wall temperatures for the three tubes just prior to the cooling transition.

The data from the two test section of Haynes 188 were also compared (test sections 2 and 3 ) for similar trends. The heat flux at which the transition to enhanced cooling occurred was between 206 and $216 \mathrm{Btu} / \mathrm{ft}^{2}$-s (234 and 245 $\mathrm{W} / \mathrm{cm}^{2}$ ) for both tubes. Fluid outlet temperature at this point was between 370 and $390^{\circ} \mathrm{F}\left(188\right.$ and $\left.200^{\circ} \mathrm{C}\right)$. The lower heat flux trigger for the Haynes 188 tubes implies that tube material may also be a factor, although there were not enough materials tested to determine whether the difference between an average transition heat flux of $210 \mathrm{Btu} / \mathrm{ft}^{2}-\mathrm{sec}\left(238 \mathrm{~W} / \mathrm{cm}^{2}\right)$ (Haynes 188) and 


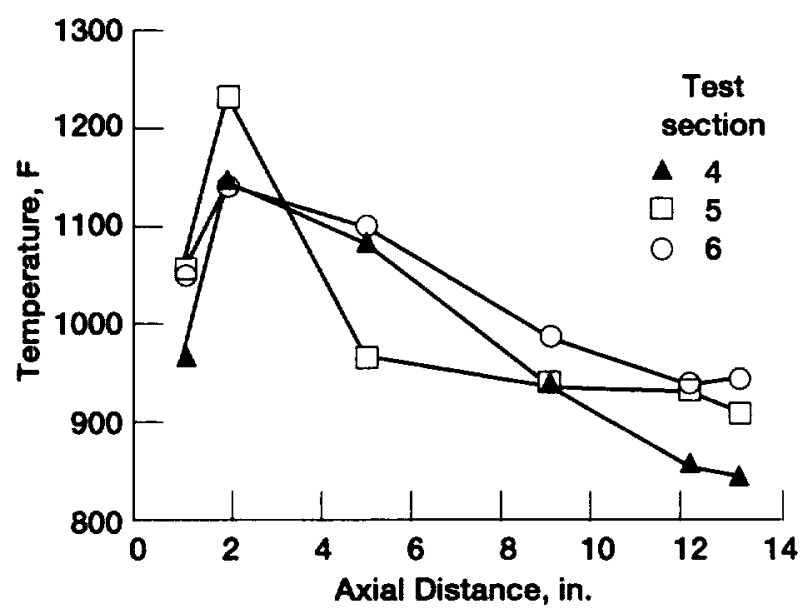

Figure 6.-Wall temperature profiles at start of enhanced cooling mechanism for Haynes 230 tubes tested.

$250 \mathrm{Btu} / \mathrm{ft}^{2}-\sec \left(284 \mathrm{~W} / \mathrm{cm}^{2}\right)$ (Haynes 230$)$ is a significant difference.

Another event that occurred at approximately the same time as the cooling transition was the onset of audible instabilities. These instabilities were normally pulsating, with several changes in pifch and frequency as heat flux increased. Similar audible instabilities have been noted in previous experiments with supercritical fluids, ${ }^{16,19,20}$ and several explanations of the cause have been proposed. In most of our test sections that were tested at higher heat fluxes (above approximately $600 \mathrm{Btu} / \mathrm{ft}^{2}-\mathrm{s}, 680 \mathrm{~W} / \mathrm{cm}^{2}$ ), the instabilities would decay as heat flux was increased. The specific heat flux at which the instabilities ceased was not determined, as the necessary instrumentation to quantify the frequency and amplitude was not installed in the test rig. The approximate time the audible instabilities stopped was noted in the log books, but they tended to subside much more gradually than they had begun. Also, the cooling data did not show any consistent reaction or change that would help locate the end of the instabilities.

All of the tubes, except for the 304 stainless steel, exhibited the audible instabilities during some portion of the test. The stainless steel tubes, however, did experience the same type of enhanced cooling that was discussed for the Haynes tubes. This indicates that although there were no audible indications, the same supercritical cooling phenomena occurred in the stainless steel tubes.

Reference 16 concluded that the vibration stresses on their tubes caused an eventual failure. Because of the similarity of Fig. 5 to typical subcritical boiling curves, we assume that the enhanced cooling was triggered by the onset of a supercritical phenomena that produces results comparable to nucleate boiling, and that this phenomena then triggered the audible instabilities. The tube failures could therefore have been a result of either runaway temperatures caused by a change to this supercritical fluid phenomena, or vibration stress caused by the instabilities. Microscopic analysis presented later in this paper shows signs that some failures were due to melting, and some were due to stress fractures.

\section{Analysis of Thermal Stability and Carbon Deposition}

After testing, the tubes were drained, sealed, and sent to Wright Laboratories for further analysis. They were sectioned such that two 4 -in. $(10.2 \mathrm{~cm})$ pieces were removed for burst testing, with other 0.5 to $1 \mathrm{in.}$ ( 1.3 to $2.5 \mathrm{~cm}$ ) pieces used for materials/surface characterization and carbon deposition measurement. No measurement of carbon deposition was made on the sections saved for burst testing. The carbon deposition measurements were performed by rinsing the tube sections in heptane to remove residual fuel and vacuum drying the tube sections at $230^{\circ} \mathrm{F}\left(110^{\circ} \mathrm{C}\right)$ for two hours. Carbon deposition measurements were performed in a Leco RC-412 Multiphase Carbon Determinator, where the carbon is "burned off" in oxygen, with the resulting $\mathrm{CO}_{2}$ quantitatively measured in an IR cell. Typical sensitivities are on the $10 \mu \mathrm{g}$ level for 1 -in. tube segments.

Carbon deposits for three of the tests are shown in Figs. 7 to 9 , along with wall temperature profiles at the maximum heat flux condition. The deposition is usually the highest at the "hot" end of the tube, where the fuel exits at 800 to $900{ }^{\circ} \mathrm{F}\left(427\right.$ to $\left.482{ }^{\circ} \mathrm{C}\right)$. The dotted lines in the figures show the locations of the copper bus bars; the tube is actively heated between the dotted lines. Carbon deposition measurements were also made on tubing on either side of the actively heated section, where the deposition was consistently found to be very low. Note that the fuel temperature on either side of the bus bar at the hot end of the tube should be very similar, yet the deposition is much lower on the unheated surface (e.g., Fig. 8). This is likely due to a lower wall temperature outside of the actively heated zone.

The deposition results are summarized in Table III, along with data from earlier tests at Wright Laboratories at lower heat flux. ${ }^{8}$ Deposition can be expressed in several ways, as either a deposition rate $\left(\mu \mathrm{g} / \mathrm{cm}^{2}-\mathrm{hr}\right)$ or as a deposition rate scaled by the total fuel flow ( $\mu \mathrm{g}$ deposit per hour/g fuel flow per hour $=\mathrm{ppm})$. The scaled deposition rate is similar for the (roughly) similar wall temperatures in the Wright Laboratories and Lewis Research Center tests, despite the much higher heat fluxes and flow rates 


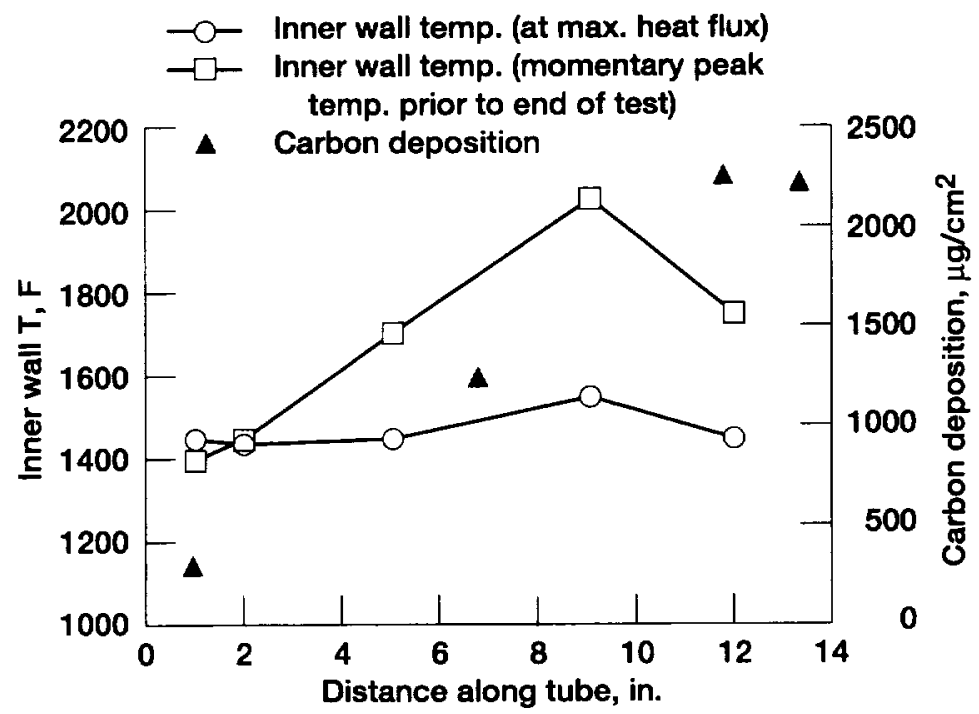

Figure 7.-Carbon deposition results for test section 2, Haynes 188.

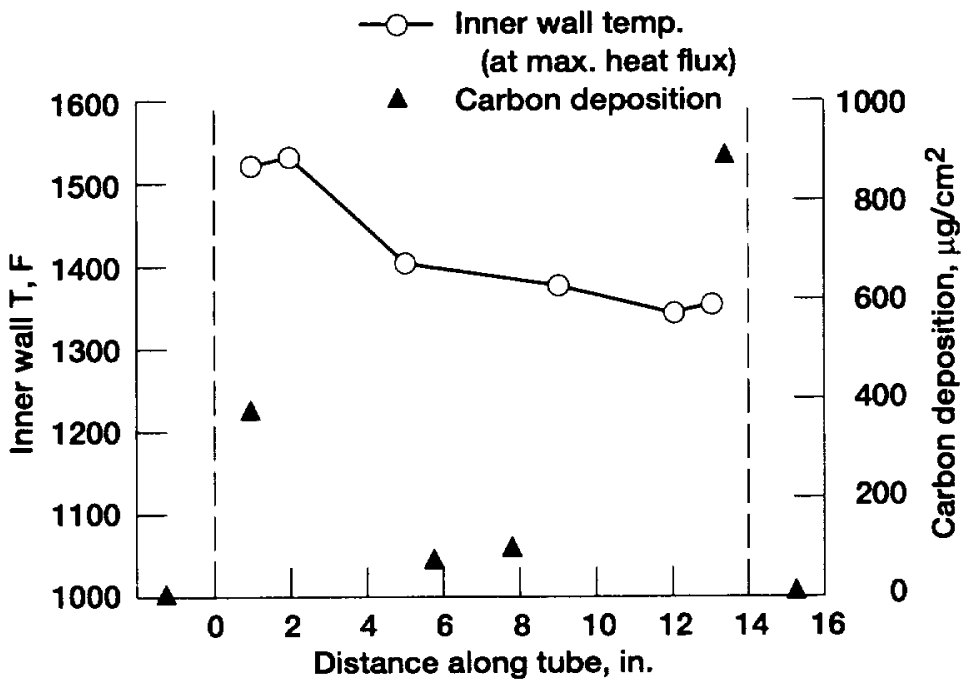

Figure 8.-Carbon deposition results for test section 4, Haynes 230. Deposition data in unheated portions of the test section are indicated at -1.5 and $15 \mathrm{in}$. along the tube. The heated portion of the tube is between the dashed lines.

(and thus the much shorter residence times) of the current tests. Note that the bulk fuel outlet temperature in the earlier tests was much higher (1200 to $1300^{\circ} \mathrm{F}$; 650 to $700{ }^{\circ} \mathrm{C}$ ), with approximately 40 percent fuel conversion (amount of cracking) because of the longer residence time. Earlier data has indicated that deposition is a complex function of fuel temperature, wall temperature, residence time, and fuel conversion. ${ }^{21}$ This data set extends the pyrolytic deposition data to much lower residence times (approximately $0.05 \mathrm{sec}$ versus approximately $1.2 \mathrm{sec}$ for the earlier tests) and higher heat fluxes.
Some of the fuel cooling characteristics discussed earlier may be explained by the carbon deposition data. For example, the deposition data for test section 5 (Fig. 9) shows significantly higher deposition near the end of the tube. The cooling capability of the fuel in this test section started out low, similar to the Dittus-Boelter Nusselt number correlation, and then transitioned to the higher cooling capability predicted by the Sieder-Tate correlation. While the first four thermocouples (at 1, 2, 5, and 9 in. from the inlet) indicated that the fuel remained at this higher cooling capability, the last two thermocouples (at 


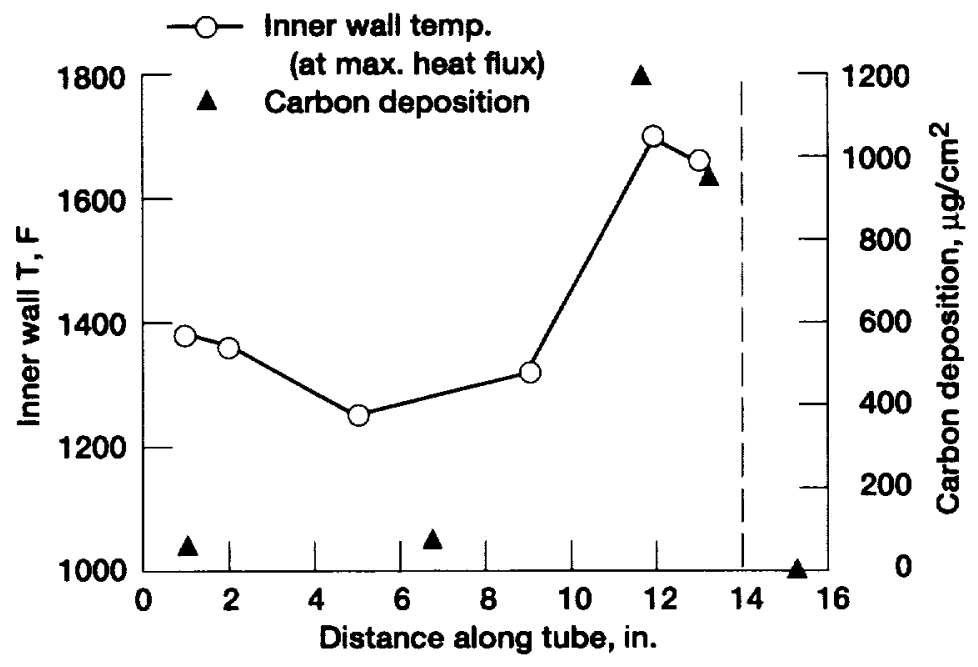

Figure 9.-Carbon deposition results for test section 5, Haynes 230.

TABLE III. -CARBON DEPOSITION RESULTS IN VARIOUS UNITS FOR SEVERAL TESTS

[NASA Lewis Research Center tests were at $0.0345 \mathrm{lbm} / \mathrm{s}$ fuel flow rate; Wright Laboratory tests were at $0.001 \mathrm{lbm} / \mathrm{s}$.]

\begin{tabular}{|c|c|c|c|c|c|c|}
\hline Test & $\begin{array}{c}\text { Maximum heat } \\
\text { flux, } \\
\text { Btu/ } \mathrm{ft}^{2}-\mathrm{sec}\end{array}$ & $\begin{array}{c}\text { Time at } \geq 1400^{\circ} \mathrm{F} \\
\text { wall temperature, } \\
\text { sec }\end{array}$ & $\begin{array}{c}\text { Maximum C } \\
\mathrm{dep}, \\
\mu \mathrm{g} / \mathrm{cm}^{2}\end{array}$ & $\begin{array}{c}\text { Maximum C } \\
\text { dep, } \\
\mu \mathrm{g} / \mathrm{cm}^{2}-\mathrm{hr}\end{array}$ & $\begin{array}{c}\text { Maximum C dep } \\
\mathrm{ppm} / \mathrm{cm}^{2} \\
\text { (scaled by fuel } \\
\text { flow) }\end{array}$ & $\begin{array}{c}\text { Wall } T \text { at } \\
\text { maximum } C \\
\text { dep }\end{array}$ \\
\hline \multicolumn{7}{|c|}{ NASA Lewis Research Center } \\
\hline $\begin{array}{l}\text { T.S. } 1 \text { (304 SS) } \\
\text { T.S. } 2 \text { (H188) } \\
\text { T.S. } 4 \text { (H230) } \\
\text { T.S. } 5 \text { (H230) } \\
\text { T.S. } 7 \text { (1617) }\end{array}$ & $\begin{array}{l}720 \\
650 \\
575 \\
650 \\
650\end{array}$ & $\begin{array}{r}200 \\
550 \\
400 \\
1000 \\
390 \\
\end{array}$ & $\begin{array}{r}1153 \\
2250 \\
900 \\
1200 \\
370 \\
\end{array}$ & $\begin{array}{r}20750 \\
14725 \\
8100 \\
4320 \\
3430 \\
\end{array}$ & $\begin{array}{l}0.06 \\
.26 \\
.14 \\
.077 \\
.06\end{array}$ & $\begin{array}{c}1400 \text { to } 1500 \\
1500^{1} \\
1350 \\
1700 \\
1500 \\
\end{array}$ \\
\hline \multicolumn{7}{|c|}{ Wright Laboratories } \\
\hline $\begin{array}{l}\text { Haynes } 188 \\
\text { Haynes } 230\end{array}$ & $\begin{array}{l}\leq 30 \\
\leq 30\end{array}$ & $\begin{array}{l}7200 \\
7200\end{array}$ & $\begin{array}{l}1428 \\
2337\end{array}$ & $\begin{array}{r}714 \\
1169\end{array}$ & $\begin{array}{r}0.45 \\
.74\end{array}$ & $\begin{array}{l}1400 \\
1400\end{array}$ \\
\hline
\end{tabular}

Upstream wall temperature reached $2000^{\circ} \mathrm{F}$ briefly at end of test as shown in Fig. 7 .

12 and 13 in.) indicated that the fuel's cooling capability was reduced at some point. This can be seen in Fig. 10, which shows the experimental Nusselt number at 12 in. compared to the two theoretical correlations. The presence of a large carbon coating on the tube at this location would serve to insulate the tube wall, thus making the fuel appear to be cooling less effectively.

One of the goals of this work is to understand fuel material interactions under the high heat flux conditions $\left(500 \mathrm{Btu} / \mathrm{ft}^{2}-\mathrm{s}\right)$ expected in hypersonic vehicles. Note that the conditions studied involve higher surface and bulk fuel temperatures than those usually encountered in regenerative cooling of rocket engines. ${ }^{22-24}$ With pyrolysis, surface deposits can form by several mechanisms. As illustrated in Fig. 11, deposits can grow via transport of large macromolecules or particles from the bulk flow, or via "catalytic" carbon formation from the surface. The illustrated mechanism is taken from the ethylene production literature, primarily for near atmospheric pressure cracking of steam-diluted hydrocarbons. It is not known at this point what effect the much higher fuel system pressures would have on this mechanism.

The previous tests at Wright Laboratories indicated that cracking of the fuel was required for deposition. 8 Their data for deposition during jet fuel cracking showed a strong dependence on fuel and wall temperature and residence time. For a given level of conversion (cracking), deposition was minimized at the shortest residence time. In these tests, because bulk fluid outlet temperature reached a maximum of only $950^{\circ} \mathrm{F}$, it was assumed that very little cracking of the fuel occurred. However, the results presented in this paper show that the deposition rates are similar to the lower heat flux results, which had a much higher conversion level for the same wall temperature. The large wall-to-fuel temperature gradient, therefore, may have enhanced one of the parallel deposition pathways in Fig. 11. For example, the high wall temperature may have accelerated filamentous carbon formation, even in the absence of bulk fuel reactions. The carbon deposits in the earlier Wright Laboratories tests were mostly 


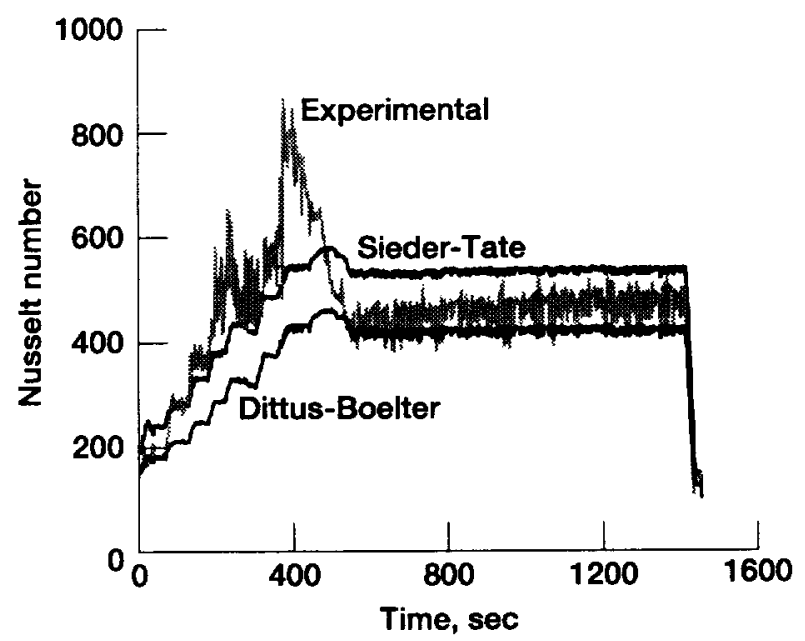

Figure 10.-Comparison of Nusselt numbers at 12 in. for test section 5, Haynes 230. Lower experimental Nusselt number after $\mathbf{5 0 0}$ seconds could indicate build-up of coke on wall surface.

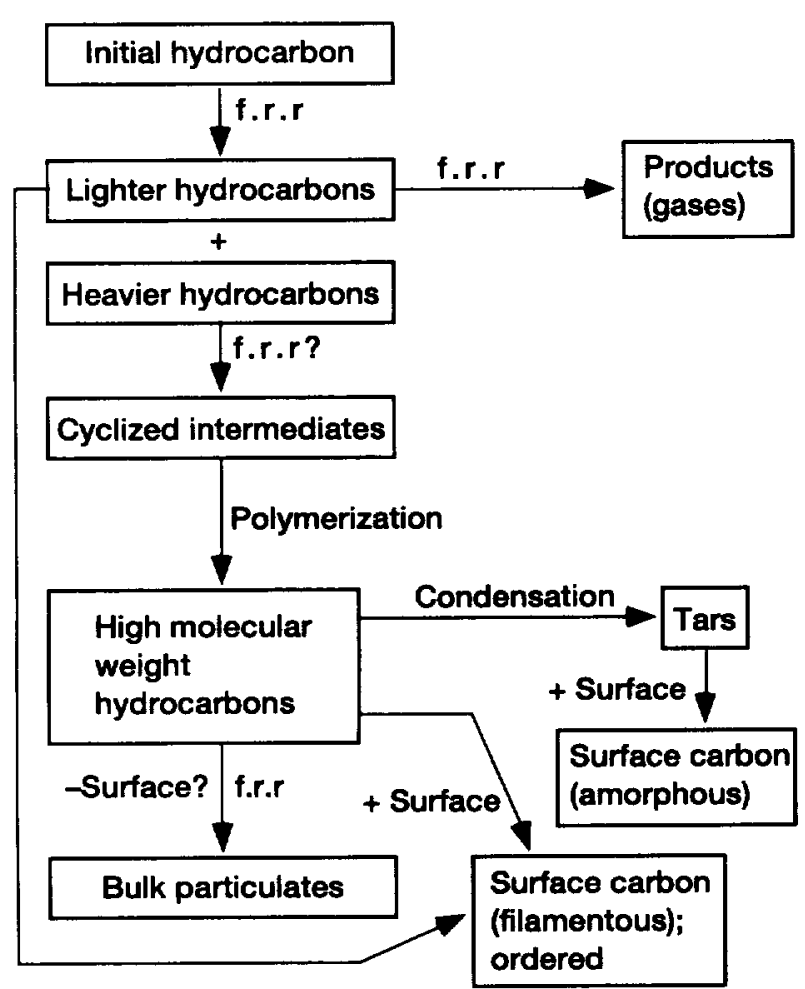

Figure 11.-Coking mechanism for pyrolysis adapted from ethylene production literature (ref. 5). Surface carbon can grow by addition of fluid phase radicals; f.r. $r=$ free radical reactions. amorphous, disordered deposits, indicative of deposition of particles from the bulk fluid. As discussed below, the deposits at high heat flux were quite different. More complete surface analyses may aid in identifying the deposition mechanism under high heat flux conditions.

\section{Microscopic Analysis}

A failure analysis was conducted on samples after testing in the NASA Lewis facility. The procedure for the failure analysis was to initially locate and characterize the appearance of the failure using low magnification photography in either the SEM or with a conventional macrocamera. This was followed by sectioning the sample to expose the interior and to use optical and electron microscopy for further characterization. Elemental scans were also made in the electron microscope using energy dispersive $\mathrm{x}$-ray spectroscopy to determine if the sample had been contaminated by the constituents in the fuel or whether the deposits from the fuel seemed to have been "seeded" by the constituents in the sample.

A typical failure of a 304 SS test section used for checkout is shown in Figs. 12 to 14. The large distortion seen in Fig. 12 indicates that the temperature of the sample was high enough to have large amounts of plastic flow due to the pressure in the tube. Several holes in the tube are also evident as is the sharp tearing indicated by the circumferential break in the tube. Figure 13 shows droplets on the torn edge as well as a small pinhole failure. At higher magnification the surface of the tube at the pinhole (Fig. 14) shows that extensive intergranular fractures have been initiated and there is a fracture that runs directly into the pinhole.

Analysis of test section 1 (304 SS) clearly showed the type of fuel decomposition that occurred during the test. The wall thickness of the sample near the failure (Fig. 15) shows a local reduction in thickness of the wall by a factor of 2, probably as a result of bulging and deformation just before failure. This would indicate that local heating was severe enough to permit deformation at low stress, which in turn led to uneven heating around the circumference of the resistively heated tube. This condition exacerbated the heating and the rate at which the strength of the tube decreased, leading rapidly to more deformation, melting, and failure. However, the thickness of the carbon deposit on each wall indicates that reaction of the fuel was nearly uniform around the circumference of the tube during most of the test.

A typical carbon deposit was examined a short distance from the failure (Fig. 16) and compared with the deposit immediately adjacent to the failure site (Fig. 17). 


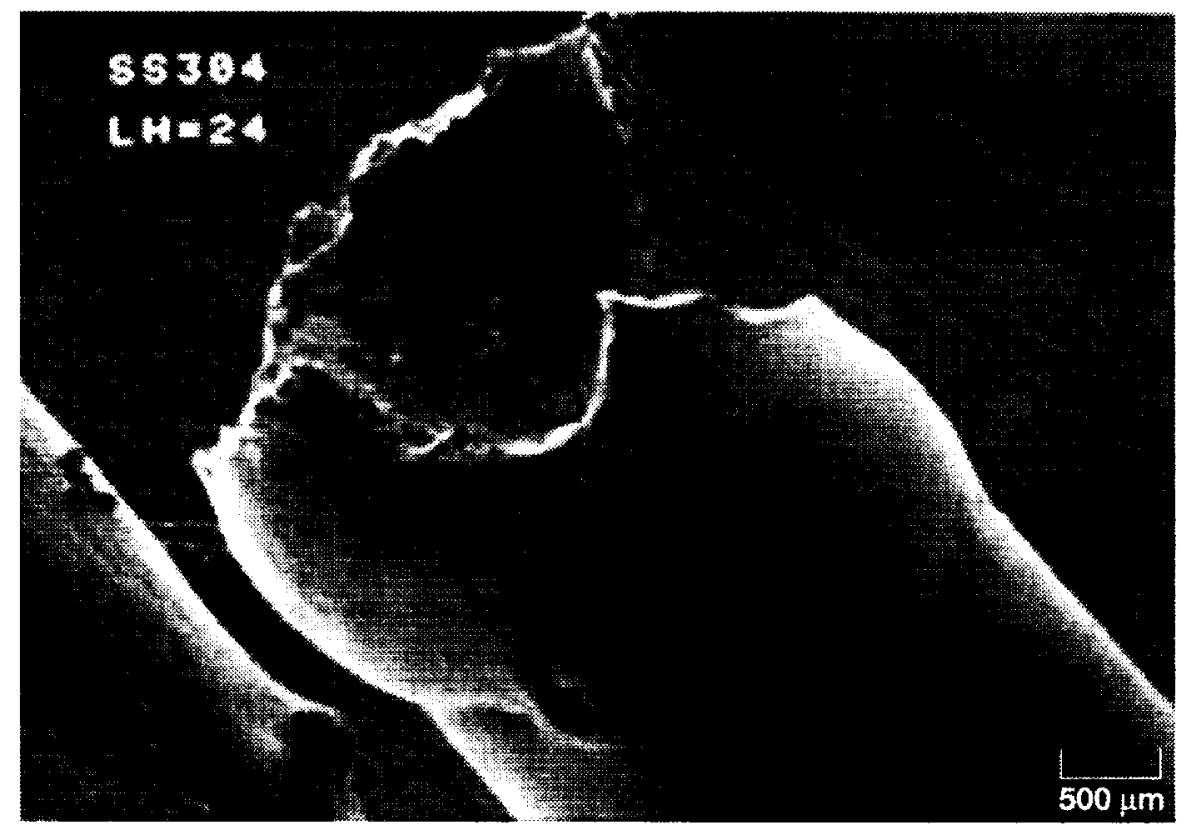

Figure 12.-Initial test failure showing pinholes and significant plastic deformation (304 SS).

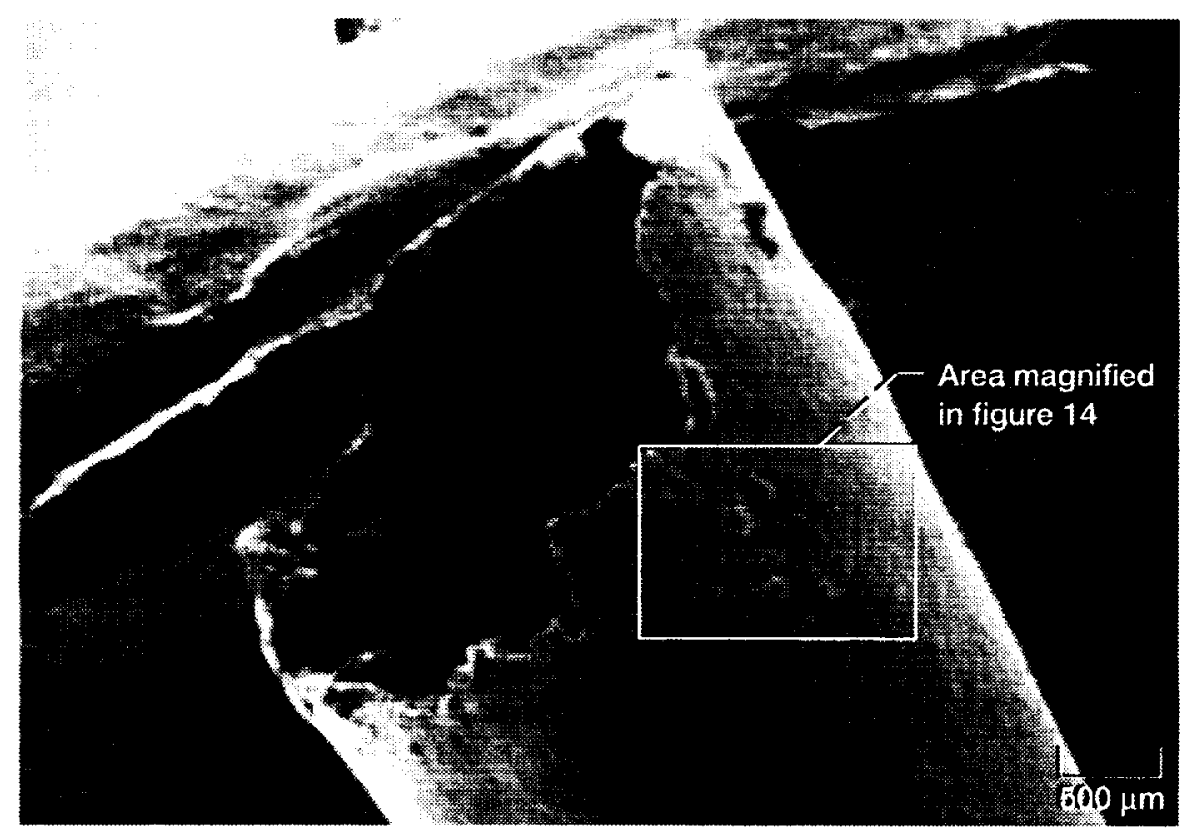

Figure 13.-Failure showing sharp tearing and melted droplets on torn edge (304 SS). 


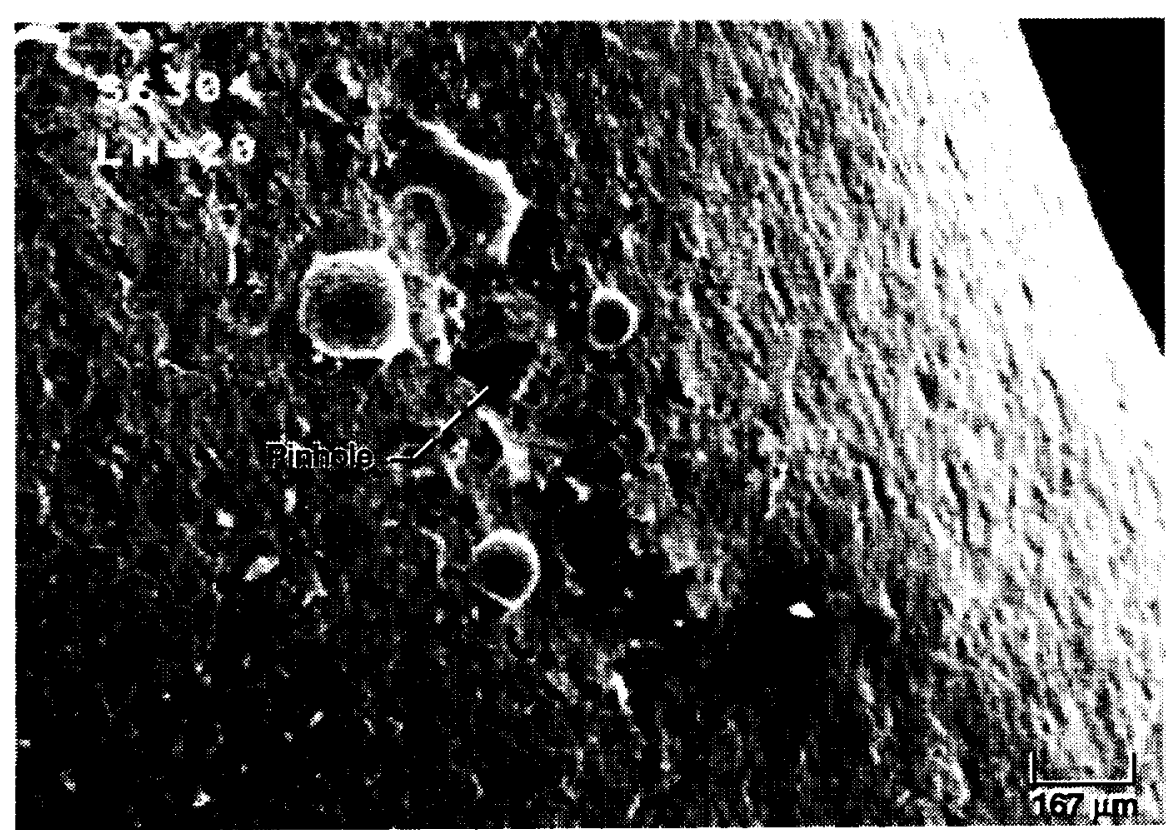

Figure 14.-Local pinhole showing granular surface indicating a local, nonmelting failure.
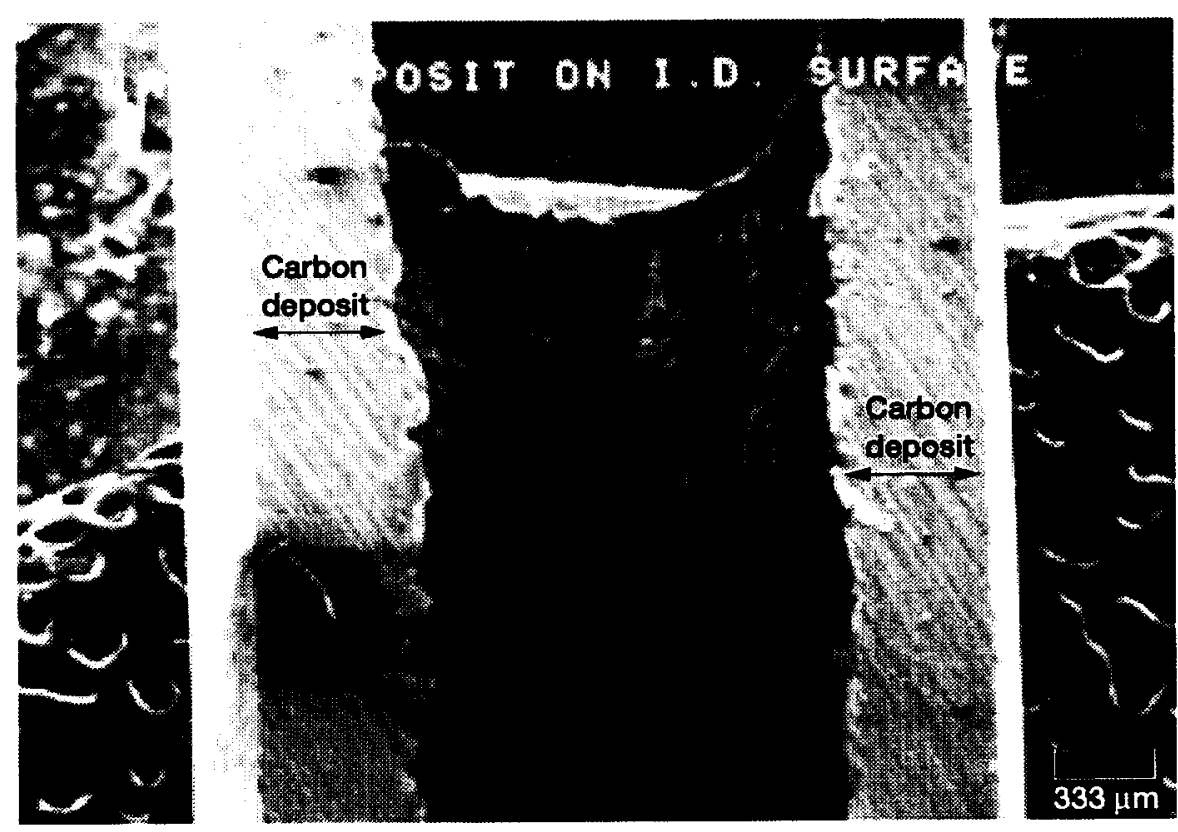

Figure 15.-Cross-section of $\mathbf{3 0 4}$ SS tube at location of failure. Significant carbon deposition is evident. 


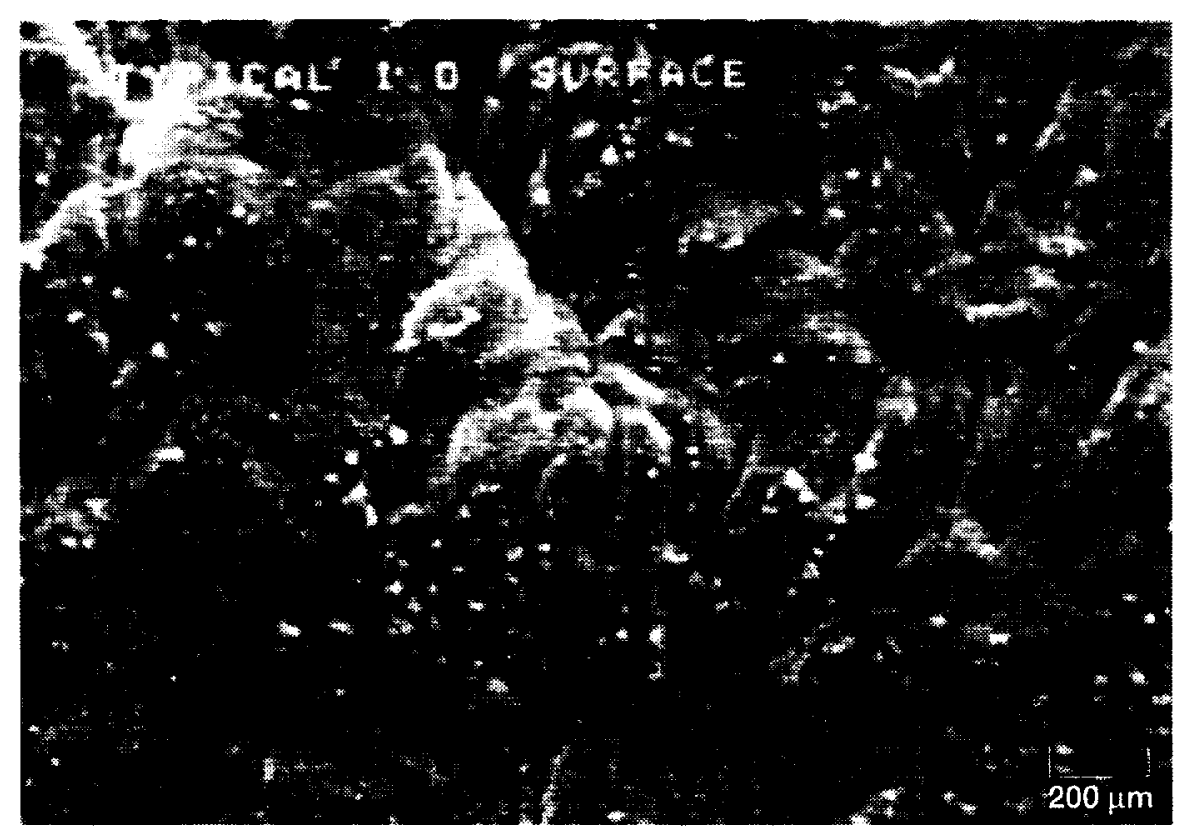

Figure 16.-Typical carbon deposit in $304 \mathrm{SS}$ tube. Granular structure indicating progressive nucleation and growth.

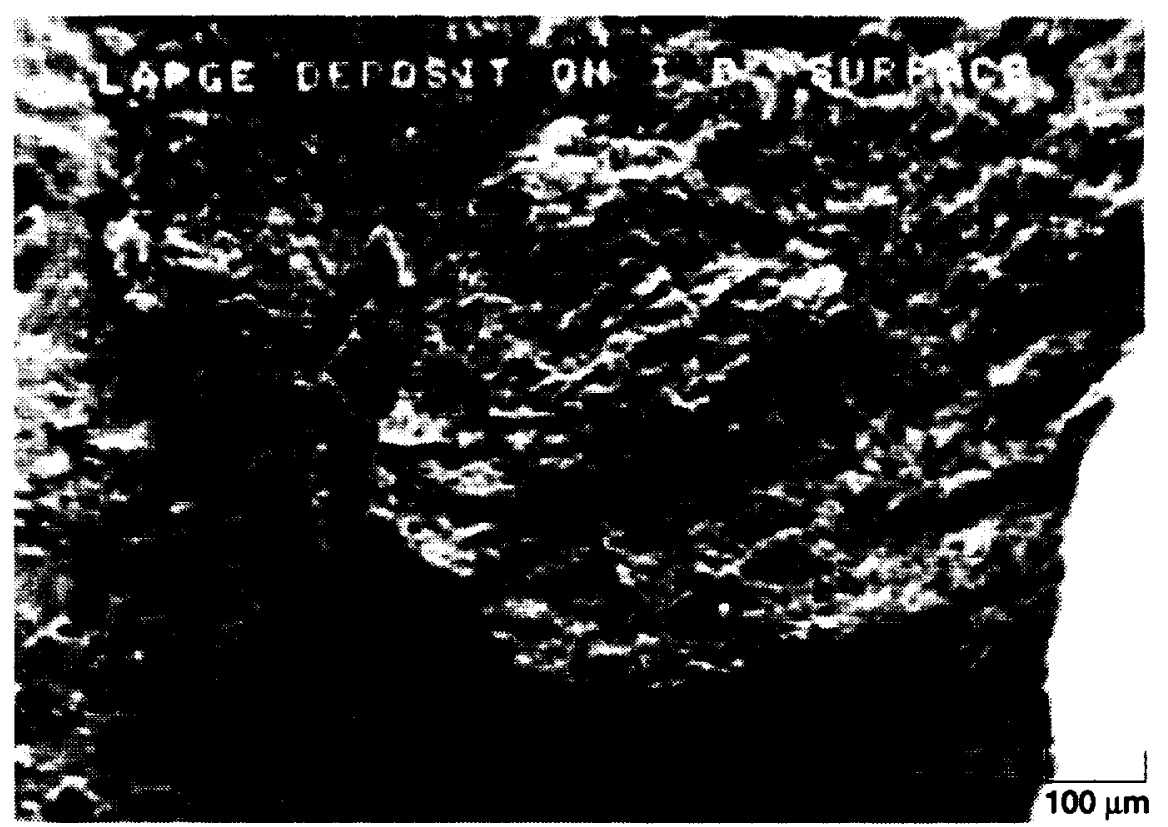

Figure 17.-Carbon deposit adjacent to failure site. Fractured and flake-like appearance. 


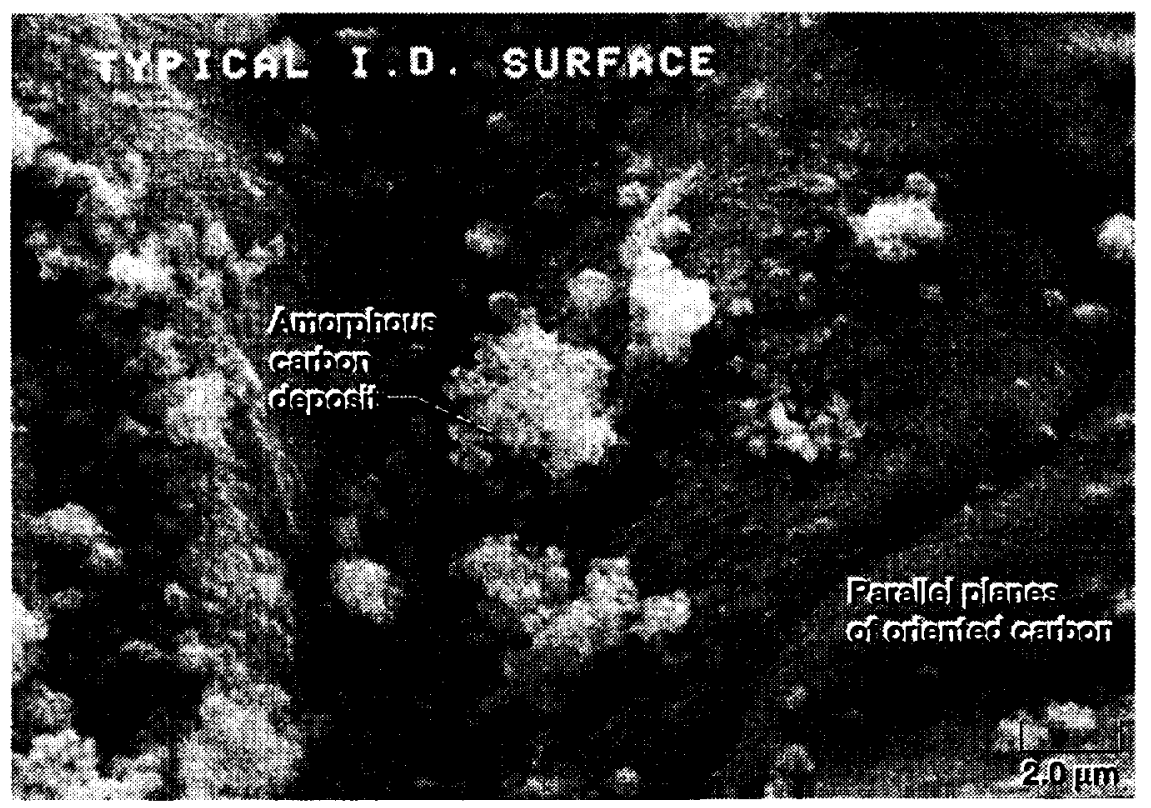

Figure 18.-Carbon deposits of figure 16 at higher magnification. Parallel layers are typical of long range order in graphic crystals.

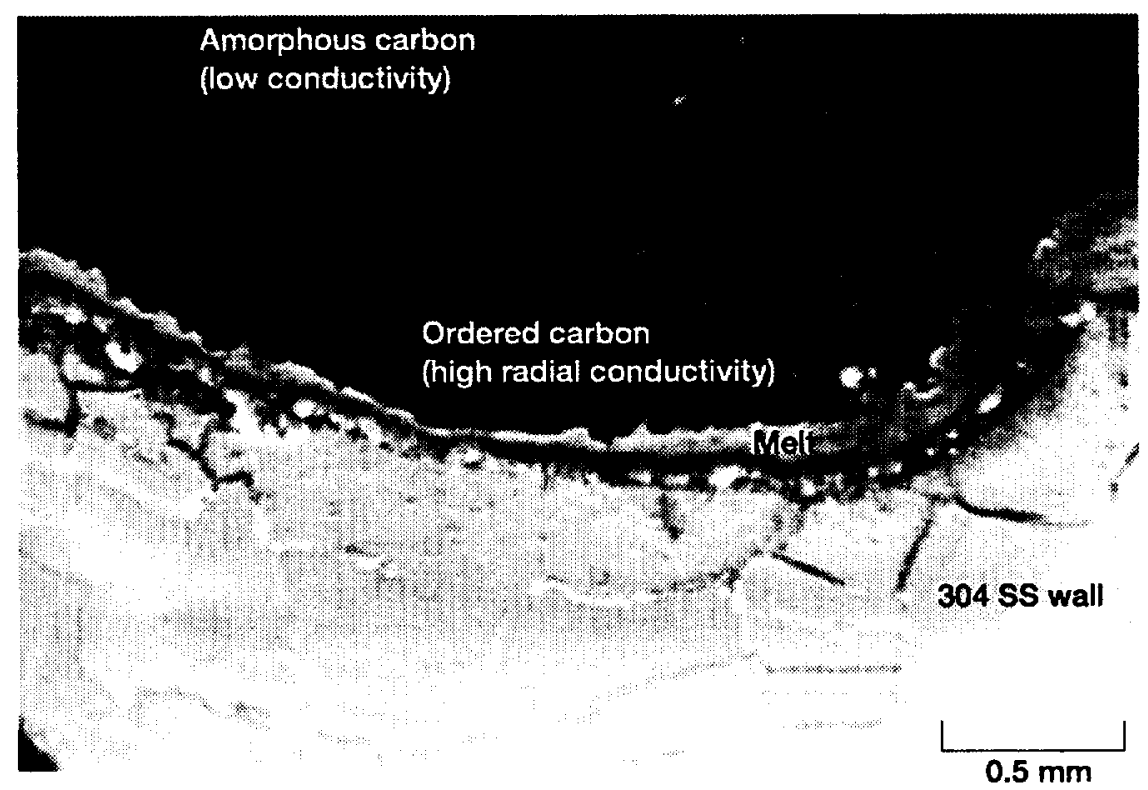

Figure 19.-Cross section of 304 SS tube showing significant layer of ordered carbon deposit with amorphous carbon deposit on top of ordered carbon. 
The typical appearance showed the development of a coherent and ordered structure indicating that progressive nucleation and growth had occurred during the test. The fractured and flake-like appearance at the failure site indicated the presence of a more porous and rapidly deposited zone generated just before failure occurred. This type of coating would have also acted as a better insulator than the dense, coherent material observed away from the failure zone. The coherent nature of the typical coating along with its lamellar structure showing long range crystallographic order is evident in Figs. 18 and 19. The lamellae on the surface (like a fingerprint pattern) shown at high magnification in Fig. 18 are edge planes intersecting the surface. The "debris" on the surface consists of carbon particles that are similar to carbon black. The cross-section in Fig. 19 shows that the orientation of the planes in the coherent deposit is perpendicular to the tube surface and the high conductivity direction is radial. This would imply that the initial deposit permitted heat transfer to occur in both the radial and circumferential directions so that the test could continue with a relatively slow growth of ordered carbon. As the carbon layer grew thicker, it may have begun to insulate the tube wall from the fluid thus promoting more rapid formation of carbon deposits which, as can be seen in Figs. 18 and 19, are more amorphous and therefore a better insulator. It is this insulating effect that probably accelerated coking, local heating, and rapid failure in the material.

\section{Conclusion}

Inconel 617, Haynes 188, Haynes 230, MolyRhenium, and 304 stainless steel heated tubes were tested at heat fluxes and JP-7 fuel flow rates that are expected to be encountered during hypersonic flight. Audible instabilities occurred in all the tests (except for 304 SS) at supercritical pressure, supercritical wall temperature, and subcritical bulk fluid temperature. These instabilities occurred simultaneous to the onset of enhanced cooling similar to that experienced by subcritical liquids in the nucleate boiling regime. However, the vibrational stresses may also have contributed to several failures of the test sections. Failures also occurred when sudden runaway temperatures caused melting.

Carbon deposition data obtained from these tests and compared to previous tests indicate roughly similar deposition rates, when scaled by fuel flow, in spite of the much higher velocity and heat flux, and much lower bulk fluid temperatures. An alternative deposition pathway, therefore, may have occurred in these tests. This conclusion is also supported by the microscopic analysis which showed that the structure of the deposits was much more ordered in the high heat flux tests, when compared to the amorphous deposits seen earlier.

\section{References}

1. Heiser, W. H., Pratt, D. T., Hypersonic Airbreathing Propulsion, AIAA, 1994.

2. Northam,G. B.,ed.,"WorkshopReport:Combustion in Supersonic Flow," 22nd JANNAF Combustion Meeting Proceedings, CPIA Publication 432, Vol. 1, 1985.

3. Newman, R. W., "Oxidation-Resistant HighTemperature Materials," Johns Hopkins APL Technical Digest, Vol. 14, No. 1, pp. 24-28, 1995.

4. Ronald, T., "Status and Applications of Materials Developed for NASP," AIAA Paper 95-6131, April, 1995.

5. Baker, R. T. K., Harris, P. S., "The Formation of Filamentous Carbon," in Chemistry and Physics of Carbon, P.L. Walker, ed, Vol. 14,pp. 83-165, 1978.

6. Reyniers, M., Froment, G. F., "Influence of Metal Surface and Sulfur Addition on Coke Deposition in the Thermal Cracking of Hydrocarbons," Industrial and Engineering Chemistry Research, Vol. 34, pp. 773-785, 1995.

7. Atria,J. V., Schobert, H.H.,Cermignani, W., "Nature of High Temperature Deposits from n-Alkanes in Flow Reactor Tubes," ACS Petroleum Chemistry Division Preprints, Vol. 41, No. 2, pp. 493-497, Mar. 1996.

8. Edwards, T., "Research in Hydrocarbon Fuels for Hypersonics," 1996 JANNAF Propulsion Meeting, Albuquerque, NM, Dec. 1996.

9. Green, J. M., Pease, G. M., and Meyer, M. L., "A Heated Tube Facility for Rocket Coolant Channel Research," AIAA-95-2936, 1995.

10. Meyer, M. L., "Electrically Heated Tube Investigation of Cooling Channel Geometry Effects," AIAA-95-2500, NASA TM-106985, 1995.

11. Edwards, T., "USAF Supercritical Hydrocarbon Fuels Interests," ALAA 93-0807, January, 1993.

12. Ely, J. F., and Huber, M. L., "NIST Standard Reference Database 4-NIST Thermophysical Properties of Hydrocarbon Mixtures," February, 1990.

13. Incropera, F. P. and DeWitt, D. P., Fundamentals of Heat and Mass Transfer, 2nd Edition, John Wiley and Sons, 1985, pp. 368-395.

14. McAdams, W. H., "Review and Summary of Developments in Heat Transfer by Conduction and Convection," Trans. AICHe, Vol. 36, p. 1, 1940. 
15. Sieder, E. N., and Tate, G. E., "Heat Transfer and Pressure Drop of Liquids in Tubes,' Ind. Eng. Chem., Vol 28, p. 1429, 1936.

16. Hines, W. S. and Wolf, H., "Pressure Oscillations Associated With Heat Transfer to Hydrocarbon Fluids at Supercritical Pressures and Temperatures," ARS Journal, pp. 361-366, March, 1962.

17. Michel, R. W., "Combustion Performance and Heat Transfer Characterization of LOX/Hydrocarbon Type Propellants," Aerojet Report 15958T-1548MA-129T-003F, Final Report (NASA Contract NAS 9-15958), April, 1983.

18. Hendricks, R. C., Graham, R. W., Hsu, Y. Y., and Medeiros, A. A., "Correlation of Hydrogen Heat Transfer in Boiling and Supercritical Pressure States," ARS Journal, pp. 244-252, February, 1962.

19. Faith, L. E., Ackerman, G. H., and Henderson, H. T., "Heat Sink Capability of Jet A Fuel: Heat Transfer and Coking Studies,"NASA CR-72951, July, 1971.

20. Hendricks, R. C., Graham, R. W., Hsu, T. Y., and Friedman, R., "Experimental Heat-Transfer Results for Cryogenic Hydrogen Flowing in Tubes at Subcritical and Supercritical Pressures to 800 Pounds Per Square Inch," NASA TN D-3095, 1966.

21. Edwards, T., Atria, J. V., " Thermal Stability of High Temperature Fuels," ASME Paper 97-GT143, June 1997.

22. Linne, D. L., Munsch, W. M., "Comparison of Coking and Heat Transfer Characteristics of Three Hydrocarbon Fuels in Heated Tubes," 32nd JANNAF Combustion Meeting, CPIA Publication 631, Vol. II, pp. 95-101, Oct. 1995.

23. Rosenberg, S. D., Gage, M. L., "Compatibility of Hydrocarbon Fuels with Booster Engine Combustion Chamber Liners," Journal of Propulsion and Power, Vol. 7, No. 6, 922-928, 1991.

24. Giovanetti, A. J., Spadaccini, L. J., Szetela, E. J., "Deposit Formation and Heat-Transfer Characteristics of Hydrocarbon Rocket Fuels," J. Spacecraft, Vol. 22, No. 5, 574-580, 1985. 


\begin{tabular}{|c|c|c|c|c|c|}
\hline \multicolumn{4}{|c|}{ REPORT DOCUMENTATION PAGE } & \multicolumn{2}{|r|}{$\begin{array}{l}\text { Form Approved } \\
\text { OMB No. 0704-0188 }\end{array}$} \\
\hline \multicolumn{6}{|c|}{ 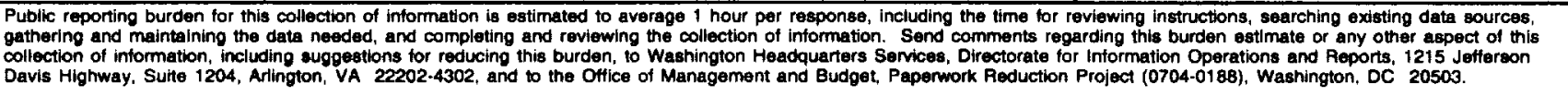 } \\
\hline \multicolumn{2}{|l|}{ 1. AGENCY USE ONLY (Laave blanK) } & $\begin{array}{r}\text { 2. AEPOAT DATE } \\
\text { July } 1997\end{array}$ & \multicolumn{3}{|c|}{$\begin{array}{l}\text { 3. REPORT TYPE AND DATES COVERED } \\
\text { Technical Memorandum }\end{array}$} \\
\hline \multicolumn{4}{|c|}{$\begin{array}{l}\text { 4. TITLE AND SUBTITLE } \\
\text { Evaluation of Heat Transfer and Thermal Stability of Supercritical JP-7 Fuel }\end{array}$} & \multirow{2}{*}{\multicolumn{2}{|c|}{$\begin{array}{l}\text { 5. FUNDING NUMBEAS } \\
\text { WU-5067-62-7K }\end{array}$}} \\
\hline \multicolumn{4}{|c|}{$\begin{array}{l}\text { 6. AUTHOR(S) } \\
\text { Diane L. Linne, Michael L. Meyer, Tim Edwards, and David A. Eitman }\end{array}$} & & \\
\hline \multicolumn{4}{|c|}{$\begin{array}{l}\text { 7. PERFORMING ORGANIZATION NAME(S) AND ADDRESS(ES) } \\
\text { National Aeronautics and Space Administration } \\
\text { Lewis Research Center } \\
\text { Cleveland, Ohio } 44135-3191\end{array}$} & \multicolumn{2}{|c|}{$\begin{array}{l}\text { 8. PERFORMING ORGANIZATION } \\
\text { REPORT NUMBER } \\
\text { E-10781 }\end{array}$} \\
\hline \multicolumn{4}{|c|}{$\begin{array}{l}\text { 9. SPONSORINGMONITORING AGENCY NAME(S) AND ADDRESS(ES) } \\
\text { National Aeronautics and Space Administration } \\
\text { Washington, DC 20546-0001 }\end{array}$} & \multicolumn{2}{|c|}{$\begin{array}{l}\text { 10. SPONSOAINGMONITORING } \\
\text { AGENCY REPORT NUMBER } \\
\text { NASA TM-107485 } \\
\text { AIAA-97-3041 }\end{array}$} \\
\hline \multicolumn{6}{|c|}{$\begin{array}{l}\text { 11. SUPPLEMENTAAY NOTES } \\
\text { Prepared for the 33rd Joint Propulsion Conference and Exhibit cosponsored by AIAA, ASME, SAE, and ASEE, Seattle, Washington, } \\
\text { July 6-9, 1997. Diane L. Linne and Michael L. Meyer, NASA Lewis Research Center; Tim Edwards, Wright Laboratory, Wright } \\
\text { Patterson Air Force Base, Ohio; David Eitman, Science Applications International Corporation, Fountain Valley, California. Responsible } \\
\text { person, Diane L. Linne, organization code 5830, (216) 977-7512. }\end{array}$} \\
\hline \multicolumn{4}{|c|}{$\begin{array}{l}\text { 12. DISTRIBUTION/AVAILABILITY STATEMENT } \\
\text { Unclassified - Unlimited } \\
\text { Subject Categories } 28 \text { and } 26 \\
\text { This publication is available from the NASA Center for AeroSpace Information, (301) 621-0390. }\end{array}$} & \multicolumn{2}{|c|}{ 12b. DISTRIBUTION CODE } \\
\hline \multicolumn{6}{|c|}{$\begin{array}{l}\text { A series of electrically heated tube experiments was conducted to investigate the potential of JP- } 7 \text { as a coolant under } \\
\text { conditions relevant to a Mach } 8 \text { propulsion system. The heat transfer capabilities, carbon deposition, and material compat- } \\
\text { ibility of JP-7 at surface temperatures up to } 1700^{\circ} \mathrm{F}\left(927^{\circ} \mathrm{C}\right) \text { were tested in } 0.125 \text { in. diameter tubes of } 304 \mathrm{SS} \text {, Inconel } \\
617 \text {, Haynes } 188 \text {, Haynes } 230 \text {, and } 50 / 50 \text { Moly-Rhenium. The heat transfer to the coolant was modeled well by a Dittus- } \\
\text { Boelter correlation at lower heat fluxes. At higher heat fluxes, audible instabilities were observed and corresponded to a } \\
\text { significant enhancement in the coolant heat transfer. The carbon deposition rates in these tests were comparable to those in } \\
\text { previous experiments at lower heat fluxes and much longer residence times. This result suggests that alternative paths of } \\
\text { the deposition mechanism may be enhanced under high heat flux test conditions. Microscopic investigation of the post test } \\
\text { tubes indicated that there was a significant layer of ordered carbon deposits that had not been seen in the tests at lower heat } \\
\text { flux. }\end{array}$} \\
\hline \multirow{2}{*}{\multicolumn{4}{|c|}{$\begin{array}{l}\text { 14. SUBJECT TERMS } \\
\text { JP-7 jet fuel; Thermal stability; Supercritical fluids; Heat transfer }\end{array}$}} & & $\begin{array}{c}\text { 15. NUMBER OF PAGES } \\
19\end{array}$ \\
\hline & & & & & 16. PRICE CODE \\
\hline $\begin{array}{l}\text { 17. SECURITY CLASSIFICATION } \\
\text { OF REPORT } \\
\text { Unclassified }\end{array}$ & & $\begin{array}{l}\text { SECURITY CLASSIFICATION } \\
\text { OF THIS PAGE } \\
\text { Unclassified }\end{array}$ & $\begin{array}{l}\text { 19. SECURTYY CLASSIFICAT } \\
\text { OF ABSTAACT } \\
\text { Unclassified }\end{array}$ & & 20. LIMITATION OF ABSTRACT \\
\hline NSN 7540-01-280-5500 & & & & & $\begin{array}{l}\text { andard Form } 298 \text { (Rev. 2-89) } \\
\text { seribed by ANSI Std. Z39-18 } \\
-102\end{array}$ \\
\hline
\end{tabular}

